This is the final peer-reviewed accepted manuscript of:

Bernini C, Cracolici MF. Demographic change, tourism expenditure and life cycle behaviour. Tour Manag. 2015;47:191-205. doi:10.1016/j.tourman.2014.09.016

The final published version is available online at:

https://doi.org/10.1016/j.tourman.2014.09.016

Rights / License:

The terms and conditions for the reuse of this version of the manuscript are specified in the publishing policy. For all terms of use and more information see the publisher's website.

This item was downloaded from IRIS Università di Bologna (https://cris.unibo.it/)

When citing, please refer to the published version. 


\title{
Demographic Change, Tourism Expenditure and Life Cycle Behaviour
}

\section{JTMA-D-13-00544 (Revised Version R3)}

\begin{abstract}
The paper explores how demographic changes in human populations may impact on tourism decision-making of households over their life cycle. By means of Hurdle Models, the study focuses respectively on the decision to travel domestically or abroad and investigates if statistically significant differences exist as to the impact of age and cohort on the decision to travel and tourism expenditure. Using a vast dataset on Italian Household Expenditures over the period 1997-2007 the empirical results show that demographic aspects do have a strong effect on the tourism behaviour of families and that cohort and age effects act differently on the decision of households to make a trip and on how much they spend on tourism. Age has a negative effect on the desire to travel but a positive effect on tourism expenditure. On the other hand, older cohorts are inclined to travel but they have a low propensity to spend on tourism. Relevant differences in income elasticity along the life cycle of households have also been found. Finally, age and cohort aspects have a different effect on the decision as to whether to travel nationally or internationally.
\end{abstract}

Keywords: Tourism expenditure, Demographic characteristics, Life cycle model, Hurdle models, Cohort technique, Domestic and international travel. 


\section{Introduction}

Nowadays the tourism sector has become the main source of income for many countries contributing strongly to their economies, generating markets for a wide variety of goods and services both directly and indirectly related to tourism (Balaguer \& Cantavella-Jordá, 2004; Eugenio-Martin \& Campos-Soria, 2011).

However, the recent report on Demographic Change and Tourism (DCT) by the World Tourism Organization and European Travel Commission (2010) has highlighted that the demographic changes in modern societies have created new challenges for the development of tourism due to their implications on tourism participation behaviour (see also Reece, 2004; Nickerson, 2000). Even before the DCT report, the German Federal Ministry of Economics and Technology published its own report on the relationship between tourism and demography in Germany. It found that demographic changes may be both an opportunity and a risk for the future development of tourism in Germany (Federal Ministry of Economics and Technology, 2009) (FMET).

According to the DCT and FMET Reports, the main socio-demographic changes that may impact on the development pattern of leisure and tourism are: a higher life expectancy, a healthier ageing population, a smaller family size, a higher share of the population with a high level of education and population migration. Without doubt these socio-demographic changes affect tourism participation behaviour; they represent external factors that shape tourism demand affecting the decision to participate in tourist activities, the type of tourist that will travel, where tourists travel to, the type of destination chosen, the length of holiday, how much to spend, etc. (see Glover \& Prideaux, 2009).

Although demography is clearly relevant - for its implications in terms of marketing policy and strategic planning - the relationship between tourism and demographic changes, in modern developed societies, has not received much attention from tourism scholars, or better the approach to it has been fragmented focusing on specific population groups like younger or senior citizens (see e.g. Fleischer \& Pizam, 2002; Glover \& Prideaux, 2009; Szromek et al., 2012; Li et al., 2013). The only exception is the paper by Yeoman et al. (2013) that presents an analysis on the relationship between demographic changes and tourism in New Zealand following a complete and holistic approach. Yeoman at al. (2013) introducing the concept of sclerosis of demography argued that demography is a key driver for future tourism demand offering opportunities but also posing threats. They stated that the "tourism industry is in a downward spiral of decline with tourists spending 
less monies year on year because of ageing populations, resulting in falling productivity and less disposable income in future years" (p.1) (see also Yeoman et al., 2013). Previously, Hall (2005; 2006) identified the ageing population as a key factor affecting the future scenario of tourism. Sedgley et al. (2011), exploring the research on tourism and ageing, advocated complementing existing approaches to the study of tourism in later life by involving gerontologists and tourism scholars, in order to help to reformulate tourism and ageing research.

It is worthy of note that, even if at a worldwide level demographic changes may be significant not all of them are relevant to the future development of tourism. FMET argued that demographic changes may be relevant to tourism only if they "arise in those groups (e.g. older people, children, the less affluent, single parents) which represent a sizeable volume, will be considerably larger or smaller in volume and whose behaviour differs from other groups" (p 6).

Along the lines of the aforementioned literature which deals with the effects of demographic changes on tourism demand and on the basis of the suggestions of the DCT and FMET Reports, this paper focuses on the relationships between demographic dynamics and the decision of people to make a trip for personal purposes and how much they spend. The study examines if and how the demographic changes occurring in Italian society affect Italian households as regards travelling and spending on leisure activities.

More specifically, this article investigates tourism spending patterns over the life cycle of households by applying a cohort approach to isolate time, socio-demographic and economic factors. This approach enables us to analyze whether changes in travel behaviour are due to the ageing process, the particular moment in history being analyzed and the personal circumstances of an individual's life.

Within this framework, the study investigates whether there are age and cohort differences as regards the tourism participation decision and tourism expenditure over the life cycle of households (see e.g. Browning, Deaton and Irish, 1985; Attanasio \& Weber, 1994; Blundell, Browing and Meghir, 1994; Jappelli, 1999; Attanasio, Banks, Meghir and Weber, 1999; Aguiar \& Hurst, 2013). The study also explores whether the impact of age and cohort is different between households travelling domestically and those travelling abroad.

The Italian context is particularly appropriate in a study on the relation between demographic changes and tourism for several reasons: over recent decades the purchasing power of households has fallen, there has been a lower rate of fertility, the population has aged and there are more people of working age without a job. There has also been an increase in voluntary childlessness which has resulted in a reduction of the average household size and has produced a large 
proportion of childless households. There has also been a decrease in official and de facto couples and an increase in one-person households.

The analysis has been performed on time series of cross-sectional data for the period 1997-2007 involving a huge sample of 253,858 households drawn from the Italian Household Budget Survey designed by the Italian Statistical Office. Conceptually, the study proposes a microeconometric tourism demand analysis enclosing the framework of the life cycle theory (Blundell, Browing and Meghir, 1994). By means of the cohort technique, we model tourism participation and expenditure over the household life cycle disentangling age, cohort and time effects (Deaton, 1985 and 1992). This enables us in a broader way to identify consumption patterns related to demographic changes (Attanasio \& Weber, 1994; Attanasio et al., 1999; Deaton, 1992). Moreover, as tourism is not a basic need, it is plausible to hypothesize that some individuals could decide not to participate in tourist activities for different reasons like budget and time constraints. Others might travel only once a year or every two or more years, thus not frequently participating in the tourist market. In all these cases individuals have zero tourist expenditures. The matter of zero tourist expenditures has been treated here by means of hurdle models that also allow control for selection bias and can simultaneously analyse the different determinants of participation and consumption decisions. As different specifications of hurdle models exist, the most suitable specification was not identified $a$ priori but by means of a statistical modelling selection.

The paper is structured in the following way. In section 2 a presentation of the life cycle theory, the cohort approach and tourism demand literature will be made. The next section presents the methodology of the study, followed by the presentation and discussion of the database and empirical findings. Some final remarks are left for the concluding section.

\section{Theoretical framework}

\subsection{Life cycle model and cohort approach}

As mentioned previously, the purpose of the paper is to examine in greater depth how and to what extent tourism consumption is affected by demographic aspects and dynamics. In doing so, the analysis of the tourism expenditure of households over their life cycle becomes the most suitable theoretical framework to identify the effects of socio-demographic characteristics on tourism demand. 
The life cycle theory assumes that the members of a household make rational choices about how much they want to spend at each age, limited only by the resources available. By building up and running down assets, working people can make provision for their retirement, and more generally, tailor their consumption patterns to their needs at different ages, independent of their incomes at each age. According to the life cycle theory, individuals build up assets during the initial stages of their working life and then, during retirement, they make use of their stock of assets. Working people save up for their post-retirement life and change their consumption patterns according to their needs at different stages of their life (Aguiar \& Hurst, 2013; Attanasio \& Weber, 1994; Attanasio, Banks, Meghir \& Weber, 1999; Blundell, Browning \& Meghir, 1994; Browning, Deaton \& Irish, 1985; Jappelli, 1999).

Empirical evidence highlights the role of the life cycle model in investigating consumption behaviour for a large set of goods and services (see e.g. Aristei et al. 2008; Chen et al. 2001; Deaton, 1992).

In tourism studies, changes in travel behaviour over a lifetime have generally been explained by the ageing process and by the stages of the family life cycle (Wells \& Gubar, 1966). For instance, Rapoport (1975) identified age as a major determinant of tourism expenditure behaviour. Age conditions the different stages of the tourist participation pattern. Lawson (1991) found that age and the stages of the family life cycle have a great affect on tourist decision-making. The family life cycle approach has been widely applied in tourism (see e.g. Collins \& Tisdell, 2002; Hong, Fan, Palmer and Bhargava, 2005; Lawson, 1991).

However, only a few studies have examined how time-related factors (i.e. time, age and birth cohort) explain changes in patterns of travel behaviour. Oppermann (1995), examining the changes in German travelling patterns and destination choices with respect to time, life cycle, and birth cohort, found that cohort differences are the important factor in changing travel patterns.

Later You \& O'leary (2000), focusing on older Japanese outbound travellers, explored by means of longitudinal and cohort comparisons whether travelers' behaviour changes over time. They found, consistent with Oppermann (1995), that the propensity to travel of elderly Japanese and what they do at a destination are affected by age group and birth cohort. They also found that the cohort effect is dominant over the age effect.

Sakai, Brown \& Mark (2000), looking at the relationship between demographic change and international travel demand in Japan, found that age is not the only determinant of tourism demand for international travel, but that birth cohorts are also relevant. Similar results were found by Alegre \& Pou (2004) who, while exploring the determinants of the probability of travel of 
Spanish tourists, discovered that age and cohort effects are relevant determinants of whether a prospective tourist goes on holiday or not.

Even if the tourism literature has highlighted the relevance of the ageing and cohort effects on tourists' participation, to our knowledge almost no empirical studies have simultaneously explored the tourism participation and tourism expenditure of households in the framework of the life cycle theory. The only exceptions are the papers by Sakai, Brown \& Mark (2000) and Alegre \& Pou (2004), which simultaneously explored age, cohort and time effects on the participation decision in tourism but not also for consumption behaviour in tourism.

The main reason limiting the use of the life cycle theory for modelling consumption is the lack of panel data. Official Statistics do not provide expenditure information for individuals over time, that is a panel data setting is not available. A possible solution is to refer to cohort techniques (Deaton, 1985). Whenever one wants to study a dynamic phenomenon using a time series of crosssectional data (i.e. not using a data set involving the same observations followed over time), one can divide the sample into groups that are homogeneous in a well-defined sense, and track the groups rather than the individuals over time. Within the framework of the life cycle theory, or whenever age is an important factor, it is natural to divide the sample according to the year of birth of the individual (or the householder) and follow the resulting 'cohorts' as they age. As underlined by Browning, Deaton \& Irish (1985), the use of cohort techniques overcomes the difficulty of studying the life cycle dynamics of variables such as consumption or income caused by the fact that observations on the same individuals at different times are not available.

The cohort approach has some appealing features in analyzing tourism consumption dynamics because it allows age, cohort and time effects on expenditure behaviour to be disentangled (Deaton, 1997). The first effect is the typical age profile associated with the biological process of ageing, reflecting decisions such as the timing of education, children and retirement. The second effect is the trend associated with cohort effects and may include improved educational attainment, changed social norms, environmental and socioeconomic experiences and wealth accumulation. The time effect accounts for the aggregate aspects that may temporarily move the households off their trend and age profiles, such as the business cycle or government policy. Studying differences in tourism participation and consumption among cohorts and across age enables policy makers and practitioners to decide how to support tourism development. 
Generally, the empirical literature explores tourism consumption behaviour without explicitly invoking the life cycle model. The literature considers the main demographic characteristics influencing the choice to make a trip, like income, education and so on.

Most of the theoretical tourism demand literature explains and interprets individual differences in tourism participation behaviour by means of the demand theory. According to the demand theory, the decision to travel is affected by income which is a budget constraint and which determines the spending capacity of individuals and consequently their utility (Crawford \& Godbey, 1991; Dardis, Derrick, Lehfeld \& Wolfe, 1981). Empirical studies show that income positively affects the decision to travel (Alegre et al., 2009; Eugenio-Martin \& Campos-Soria, 2011; Fleisher \& Rivlin, 2009; Mergoupis \& Steuer, 2003), and its effect is higher for individuals with medium or high levels of income (Fish \& Waggle, 1996; Hay \& McConnell, 1979; Nicolau \& Más, 2005). Generally, the income elasticity is below the unit value (Alegre \& Pou, 2004; Melenberg \& van Soest, 1996), and has a value greater than one for the decision to travel abroad or to spend (Bernini \& Cracolici, 2014; Eugenio-Martin \& Campos-Soria, 2011; van Soest \& Kooreman, 1987).

Furthermore, as tourism is becoming a 'necessary' good (i.e. income elastic), it is influenced not only by the current income but also by the forecast of future income. Usually, future income expectations are proxied by variables like employment status, job stability and level of education that also reflect socio-demographic aspects of the structure of the population. Other studies include as economic determinants variables related to the tenure status of the house as a proxy for credit constraints (Alegre, Mateo \& Pou, 2010; Jang \& Ham, 2009).

As far as socio-demographic aspects and this effects on tourism are concerned, it is worth noting that changes in the composition and size of the household may bring variations in participation and spending behaviour. The size and composition of the family (i.e. the number of children and/or elderly persons) affect household preferences regarding participation, destination choice, amount of money to spend, etc. Smaller families with no children are likely more inclined to travel than large families which have more economic and physical constraints (Collins \& Tisdell, 2002; Nicholau \& Más, 2005).

Among the other socio-demographic characteristics of individuals that may act on the tourism participation process, the role of the level of education, occupation and gender of the householder should be highlighted. Education and employment are usually used as proxies of future income expectations and to represent social class differences (Alegre \& Pou, 2004; Alegre et al., 2010; Cai, 
1998, 1999). Regarding the level of education, empirical studies show that it positively affects the decision to travel and the level of consumption (Alegre \& Pou, 2004; Nicholau \& Más, 2005; van Soest \& Kooreman, 1987).

A higher level of education broadens an individual's access to information and knowledge, and it also indirectly reflects income constraints. In fact, those with higher levels of education are more likely to have the chance to get a good job and to earn high levels of income giving their family the opportunity to dispose of more money on tourism. As far as employment is concerned, it reflects both time and economic constraints. Empirical studies show that being a student positively affects the likelihood of making a trip; while the unemployed are less prone to travel than managers or self-employed professionals (van Soest and Kooreman, 1987; Eugenio-Martin \& Campos-Soria, 2011).

Regarding gender, even if the literature on tourism participation emphasizes the role played by gender, some studies find that gender does not significantly affect the tourism participation decision or tourism expenditures. That could be due to the fact that the decision to participate in tourism does not involve a single person but a group of people; viz. the decision of the head of the household reflects the tourist preferences of the family. However, some studies show men and women could have different reasons for going on holiday and that they prefer different kinds of holiday (Eugenio-Martin \& Campos-Soria, 2011; McGehee, Loker-Murphy \& Uysal, 1996).

Most recently, empirical analysis has also emphasized the role played by population location and consequently the attributes of the tourist's place of residence (World Tourism Organization and European Travel Commission, 2010). Eugenio-Martin \& Campos-Soria (2011), considering both socio-economic characteristics and the regional attributes of the residence place of the household, propose an extension of the participation analysis from the national to the regional level. Mergoupis \& Steuer (2003) consider the territorial attributes of the residence place of the family using regional dummies. These studies have found that geographical variables have a significant effect on the decision to participate in tourism and on the amount of spending on it. It is reasonable to hypothesize that people living in a less attractive tourist region are more inclined to go on holiday to explore new destinations and to have new experiences (Eugenio-Martin \& Campos-Soria, 2011). On the other hand, people located in urban and developed areas have more flexibility to travel than individuals living in rural and developing territories. 


\section{The method}

\subsection{Modelling tourism demand over the life cycle}

Using time series of cross-sectional data, we identify life cycle effects by building synthetic cohorts. This enables us to model tourism participation and expenditure over the life cycle disentangling age, cohort and time effects (Attanasio \& Weber, 1994; Aristei et al., 2008; Aguiar \& Hurst, 2013), as follows:

$\ln C_{t}^{c h}=\delta_{t}^{c}+\beta \pi_{t}^{c h}+\varepsilon_{t}^{c h}$

where $C_{t}^{c h}$ is the observed tourism expenditure of household $h$, whose head is $a$ years old at time $t$ and belongs to the cohort $c$; $\pi_{t}^{c h}$ is a vector of variables characterizing the householder (i.e. income, sex, residence, education, job position, etc.). $\delta_{t}^{c}$ represents the age expenditure profile obtained by the sum of a polynomial in age $f($ age $)$, cohort dummies $\alpha^{c}$ and time dummies $\tau_{t}, 1$ as follows:

$\delta_{t}^{c}=\alpha^{c}+\tau_{t}+f($ age $)$

The synthetic cohort approach allows us to investigate the dynamic behaviour of tourism participation over the life cycle. By decomposing the tourism expenditure into cohort and age effects, we obtain a clearer picture of the different patterns of consumption that highlights possible changes in preferences between older and younger people and differences in the tourism expenditure decision and the consumption level amongst successive cohorts.

To investigate ageing and cohort effects in tourism consumption, a double-log specification for the tourism demand model is proposed

\footnotetext{
${ }^{1}$ It is to be noted that when the cohort technique is used an identification problem occurs. Age, cohort and time effects, without additional information and/or structure, are not identifiable separately due to the linear relation between age, year of birth, and current year. A possible solution to circumvent this identification problem is to assume that time effects (business cycle) average to zero and are orthogonal to linear trends. This is equivalent to assuming that all (linear) trends in the data can be interpreted as a combination of age and cohort effects. This basic identification assumption allows a typical age profile to be estimated and the movements of this profile among the cohorts considered to be assessed (MaCurdy \& Mroz, 1990; Deaton \& Paxson, 1994).
} 
$\ln C_{t}^{c h}=\alpha^{c}+\tau_{t}+f($ age $)+\beta_{I} \ln$ Income $_{t}^{c h}+\beta_{I 2} \ln$ Income ${ }_{t}^{2 h}+\varepsilon_{t}^{c h}$

where a household's income enters the demand equation both in the level and squared form. The double-log function has often been used in empirical studies of tourism demand because it is flexible and better fitting (see Alston et a. 2002). Moreover, the demand model in Eq. (3) allows us to easily construct tourism elasticity with respect to income. Actually, in tourism participation literature the concept of income elasticity is used in a wider sense than the economic one. Income elasticity is used to refer not only to the effect of the relative change of income on tourism expenditures (i.e. in a strict sense), but also to the impact of income change on the probability of making a trip. In the literature, there are few examples of studies on tourism expenditure reporting income elasticity in a strict sense (Bernini \& Cracolici, 2014; Melenberg \& Van Soest, 1996; van Soest \& Kooreman, 1987). We construct income elasticities from Eq. (3) as follows (Blundell et al., 1993):

elast $_{t}^{c h}=\beta_{I}+2 \beta_{I 2} \ln$ Income $_{t}^{c h}$

\subsection{Handling tourism zero expenditure}

Tourism like other goods may not be consumed by everyone; i.e. not all individuals participate in tourism activity thus reporting values of expenditure equal to zero. So, the above model in Eq. (3) should be revisited to account for a large proportion of observations with a value of tourism expenditure equal to zero.

There are several reasons why an individual might not consume a good (like tourism) at a given time. One of the reasons for observed zero expenditures is that the market price for goods exceeds the individual's reserve price, leaving the individual at a corner solution and the expenditure distribution is censored at the point of non-consumption. This is why the Tobit model has been used (Tobin, 1958) to estimate censored expenditure relationships. Under the Tobit formulation, the same variables are assumed to determine both the value of the continuous observations and the discrete switch to non-consumption at zero, making it only appropriate in cases where consumers are rationed out of the market by prices higher than they are willing to pay. 
The standard Tobit specification is formally defined as

$y_{i}^{*}=\beta^{\prime} x_{i}+\varepsilon_{i}$ with $\varepsilon_{i} \rightarrow N\left(0, \sigma^{2}\right)$ and i:1,..N

$y_{i}= \begin{cases}y_{i}^{*} & \text { if } y_{i}^{*}>0 \\ 0 & \text { otherwise }\end{cases}$

where $y_{i}^{*}$ is the latent endogenous variable representing individual i's desired level of consumption, and $y_{i}$ is the corresponding actual observed expenditure. $x_{i}$ is a set of individual characteristics that explain both participation and level of expenditure; $\beta$ is a corresponding vector of parameters to be estimated. In this model, $\varepsilon_{i}$ is a homoskedastic and normally distributed error term. From Eq. (5b) the tourism expenditure assumes positive continuous values if travelling is desired; while zero is due to an individual being censored by economic factors in the tourism consumption equation.

The standard Tobit model is estimated using the maximum likelihood method. The log likelihood function for this estimation is:

$$
L L=\sum_{0} \ln \left[1-\phi\left(\frac{\beta^{\prime} x_{i}}{\sigma}\right)\right]+\sum_{+} \ln \left[\frac{1}{\sigma} \varphi\left(\frac{y_{i}-\beta^{\prime} x_{i}}{\sigma}\right)\right]
$$

where 0 indicates summation over the zero observations in the sample $\left(y_{i}=0\right)$ and + indicates summation over positive observations $\left(y_{i}>0\right) . \phi$ and $\varphi$ are the standard normal distribution and density functions, respectively.

Other situations for zero expenditure values are the result of the infrequency of purchase, which occurs when the purchase of some commodities is not observed due to the short span of the survey period. According to this mechanism, once a consumption decision has been taken, the individual decides when to buy the good but zero expenditure may be observed if the survey by which this data is collected is carried out over too short a period with respect to the frequency at which the good is bought. This censoring mechanism was introduced in empirical demand analysis by Deaton \& Irish (1984). It allows us to account for the non-purchase of a good not because the good is not consumed but because it is a good which is infrequently bought. 
Furthermore, the non-consumption of a good may be a consequence of a fundamentally noneconomic decision motivated by ethical, psychological or social considerations affecting the consumer's preferences. According to this mechanism, the individual first decides which goods to include in his/her choice set and, as a consequence, he/she can discard some marketed goods because he/she dislikes them (such as wine for non-drinkers) or considers them harmful (such as holidays in dangerous countries), among others. Popular among models accounting for infrequently consumed goods or non-economic factors generating zero observations is the double hurdle model by Cragg (1971).

The Cragg model (CM) assumes that an individual has to desire a positive amount of good or service (first-hurdle: the participation decision), and secondly, there must be favourable circumstances for a positive expenditure to occur (second hurdle: the consumption decision). According to Cragg (1971), a non-zero tourism expenditure can thus occur if the individual decides to travel and he/she actually spends money on tourism. The double-hurdle model assumes that zero values can be reported at both decision stages. The zeros reported at the firststage arise from non-travelling and those in the second stage come from non-consuming due to the respondents' deliberate decisions or random circumstances. Thus, the $\mathrm{CM}$ allows for the fact that the potential traveller (i.e. the individuals participating in tourism) may have zero tourism expenditure. An interesting feature of the $\mathrm{CM}$ model is that different sets of determinants affect the two hurdles. Separating the two decision stages is particularly relevant in modelling tourism consumption, since the decision to travel can be assumed as mainly related to social factors, and the decision about how much to spend on a trip depends on individual budget constraints.

According to Cragg (1971), the double hurdle model is specified in the following way:

participation decision: $d_{i}^{*}=\alpha^{\prime} z_{i}+v_{i} \quad v_{i} \rightarrow N(0,1)$

$$
d_{i}=\left\{\begin{array}{llr}
1 & \text { if } & d_{i}^{*}>0 \\
0 & & \text { otherwise }
\end{array}\right.
$$


consumption decision: $y_{i}^{*}=\beta^{\prime} x_{i}+u_{i} \quad u_{i} \rightarrow N\left(0, \sigma^{2}\right)$

$$
y_{i}=\left\{\begin{array}{cc}
y_{i}^{*} & \text { if } d_{i}=1 \text { and } y_{i}^{*}>0 \\
0 \quad \text { otherwise }
\end{array}\right.
$$

where $x$ and $z$ are a different set of variables affecting the two decision stages and both variables are also assumed to be uncorrelated to their respective error terms; $d_{i}^{*}$ is a latent variable that denotes binary censoring and $y_{i}^{*}$ the unobserved latent value of expenditure. Eq. (8b) indicates that the observed expenditure $y_{i}$ is zero either when there is censoring at zero $\left(y_{i}^{*} \leq 0\right)$ or if there is faulty reporting, or due to some random circumstance. In other words, a positive level of tourism consumption $\left(y_{i}=y_{i}^{*}\right)$ is observed only if the individual is a potential tourist $\left(d_{i}=1\right)$ and actually consumes tourism $\left(y_{i}^{*}>0\right)$.

The original formulation of the $\mathrm{CM}$ also assumes that:

$$
\left(v_{i}, u_{i}\right) \rightarrow \operatorname{BVN}(0, \Gamma), \quad \Gamma=\left[\begin{array}{cc}
1 & 0 \\
0 & \sigma^{2}
\end{array}\right]
$$

where $B V N(0, \Gamma)$ denotes the bivariate normal distribution with mean zero and standard deviation $\Gamma$, and having assumed that $\rho$ (i.e. the correlation coefficient of the $v_{i}$ and $u_{i}$ terms) equals zero, that is the error terms in Eq. (7a) and (8a) are independent. ${ }^{2}$

The double-hurdle model with independent error terms can be estimated by the following log likelihood function:

$$
L L=\sum_{0} \ln \left[1-\phi\left(\alpha^{\prime} z_{i}\right) \phi\left(\frac{\beta^{\prime} x_{i}}{\sigma}\right)\right]+\sum_{+} \ln \left[\phi\left(\alpha^{\prime} z_{i}\right) \frac{1}{\sigma} \varphi\left(\frac{y_{i}-\beta^{\prime} x_{i}}{\sigma}\right)\right]
$$

where the first term includes all the observations with an observed zero, that is the zero observations come not only from the participation decisions but also from the consumption decisions. The second term in Eq. (10) includes all the observations with non-zero expenditure. The probability in the second term is the product of the conditional probability distribution and the density function coming respectively from the censoring rule and from observing non-zero values.

\footnotetext{
2 A Cragg model with dependent error term has also been proposed. Assuming that the error terms of the participation and consumption equations are correlated allows for the possibility that the two decisions are made simultaneously.
} 
Therefore, the former denotes the probability of passing the participation hurdle, and the latter indicates the density of observing non-zero tourism expenditure.

The problem of zero observations also has close links to the problem of selection bias. Sample selection bias may arise in practice for two reasons; it may be self selection by the individuals being studied; or sample selection decisions by researchers operating in much the same fashion as self selection. Both cases have the same effect on structural estimates: fitted regression functions confound the behavioural parameters of interest with parameters of the function determining the probability of entrance into the sample. From a methodological perspective, Heckman (1979) shows that bias resulting from using non-randomly selected samples to estimate behavioural relationships may be treated as a specification error and proposes a simple consistent estimation method that eliminates the specification error in the case of censored samples. Heckman overcomes the sample selection problem by undertaking a two-step estimation procedure: a full sample Probit estimation is followed by a censored estimation carried out on the selected subsample.

While the former estimates the probability of observing a positive outcome (participation equation), the latter estimates the level of consumption conditional on observing positive values (consumption equation). More specifically, the Heckman model (HM) considers that zero observations arise mainly from respondents' self-selection, that is all the zeros come from the respondents' deliberate choices. In the case of tourism expenditure only non-travelling respondents can report zero tourism expenditure, while those who travel do not report zero values at all. Using the Heckman model, a different set of determinants can be considered for each stage of the decision; viz. the participation equation involves social and demographical factors, while the consumption equation is affected by economic variables.

As for the model specification, the HM differs from the $\mathrm{CM}$ in the threshold consumption equation (Eq. 8b), as follows

consumption decision: $y_{i}^{*}=\beta^{\prime} x_{i}+u_{i} \quad u_{i} \rightarrow N\left(0, \sigma^{2}\right)$

$$
y_{i}=\left\{\begin{array}{cc}
y_{i}^{*} & \text { if } d_{i}=1 \\
0 & \text { otherwise }
\end{array}\right.
$$

where $\mathrm{z}$ is a different set of variables from $\mathrm{x}, \mathrm{x}$ and $\mathrm{z}$ variables are uncorrelated to their respective error terms. In the Heckman model, the error terms of the two equations are assumed to be correlated and the structure of the model is recursive, so the identification requires there be at least 
one variable in $\mathrm{z}$ that does not appear in $\mathrm{x}$. Following the HM approach, the observed tourism expenditure $y_{i}$ equals the unobserved latent value $y_{i}^{*}$ only for individuals having decided to travel (i.e. tourists).

The Heckman model assumes that $\rho$ (i.e. the correlation coefficient of $v_{i}$ and $u_{i}$ is different from 0 , thus

$\left(v_{i}, u_{i}\right) \rightarrow B V N(0, \Gamma), \quad \Gamma=\left[\begin{array}{cc}1 & \rho \sigma \\ \rho \sigma & \sigma^{2}\end{array}\right]$

The estimation procedure is as follows: in the first stage of the Heckman model, all observations are used to estimate a probit model of $d_{i}$ on $z_{i}$ to obtain estimates of $\hat{\alpha}$ and allowing the inverse Mills ratio $\hat{\lambda}_{i}=\lambda_{i}\left(\frac{\hat{\alpha}^{\prime} z_{i}}{\sigma}\right)$ to be computed. The $\hat{\lambda}_{i}$ is thus added as an instrument in the second-stage model, approximating a variable representing the unobservable influences on the participation decision to correct for sample selection bias. If $\hat{\lambda}_{i}$ is significant, the sample selection bias is present but has been corrected. The log likelihood function for this specification is:

$L L=\sum_{0} \ln \left[1-\phi\left(\alpha^{\prime} z_{i}\right)\right]+\sum_{+} \ln \left[\phi\left(\frac{\alpha^{\prime} z_{i}+\frac{\rho}{\sigma}\left(y_{i}-\beta^{\prime} x_{i}\right)}{\sqrt{1-\rho^{2}}}\right) \frac{1}{\sigma} \varphi\left(\frac{y_{i}-\beta^{\prime} x_{i}}{\sigma}\right)\right]$

Furthermore, if the error terms in (7a) and (11a) are assumed to be independent $(\rho=0)$, the above specification can be further simplified. For independent error terms, Eq. (13) reduces to

$$
L L=\sum_{0} \ln \left[1-\phi\left(\alpha^{\prime} z_{i}\right)\right]+\sum_{+} \ln \left[\phi\left(\alpha^{\prime} z_{i}\right) \frac{1}{\sigma} \varphi\left(\frac{y_{i}-\beta^{\prime} x_{i}}{\sigma}\right)\right]
$$

In this case, the Heckman model is named 'Full dominance hurdle model'. Differently from the Cragg model, HM assumes all the zeros are generated only by the non-participation decision. A comparison of the first term of Eq. (14) with that of Eq. (10) reveals that the additional $\phi\left(\frac{\beta x_{i}}{\sigma}\right)$ 
depicts the contribution of the double-hurdle model, so zero values in the second stage decision can be observed.

In summary, $\mathrm{HC}$ and $\mathrm{CM}$ models follow a similar approach in the treatment of the zero outcomes. They both assume that outcomes are determined by the participation and consumption decisions and they allow the first- and second-stage equations to be estimated using different sets of explanatory variables. However, the HM model, in contrast to CM, assumes that only travelling respondents report tourism expenditure. So, the Heckman model is also called the 'first hurdle dominance model'. Conversely, the CM takes into account that individuals participating in tourism may have zero tourism expenditure, due to deliberate decisions or random circumstances. In the light of that, the $\mathrm{CM}$ model can be considered an improvement on both the Tobit and the Heckman models.

The Heckman and Cragg models differ from the Tobit model for two reasons. First, these models assume the decision-making process of the consumer to be a two-stage decision, and secondly, they permit the use of different sets of explanatory variables at the two stages of estimations. Consequently, the HM and CM models can be viewed as a generalization of the Tobit model.

Since it is implausible that all zero observations in tourism expenditure arise from standard corner solutions generated by a constrained budget, the importance of hurdle specifications are clear. Moreover, not having an a-priori knowledge of the determinants of zero tourism expenditure, we adopt a data-driven approach to the selection of the model, allowing the choice of the best model for zero tourism consumption to be empirically determined.

\section{Data and Model}

\subsection{Data and some descriptive statistics}

The empirical analysis has been performed on the data from the Households Budget Survey (BF), carried out by the Italian Office of Statistics (ISTAT). A sample of 265,028 households was collected over the period 1997 to 2007. With regard to tourism, BF observes the monthly total amount of expenditure of the household on trips for personal purposes. Following the international standards, BF records, both for national and international trips, expenditure on holiday, leisure and recreation, visiting friends and relatives, health treatment, religious activity 
and pilgrimages, etc. The Survey does not provide information about the reason for the trip, so it is impossible to investigate how it affects tourism expenditure. We use 'tourism expenditure' below to refer to expenditure on trips for personal purposes.

The respondent is a member of the household, usually the householder, who reports the tourism expenditure of all members of the family. The survey does not provide information about the number of household members making a trip; but it does indicate if Italian families travel abroad or in the country and if they report a expenditure other than zero.

Data on expenditure is supplemented by a rich set of economic, demographic, and sociological variables on Italian households. BF survey is performed every year and involves a random sample of the population. A pool of time series of cross sectional observations can thus be set up and groups of households can be followed over time by means of cohort techniques (Deaton, 1985). The cohorts have been identified by using the age of the head of the household.

Following Attanasio \& Weber (1994), Browning et al. (1985) and Deaton (1985), we group households on the basis of the age of the householder, using five-year age band cohorts, and track the cohorts over time. The age of each householder (i.e. ' $a$ ') is defined as the mid-range age of the age-class ${ }^{3}$ which the household head belongs to, while cohort ' $c$ ' is defined as $c=t-a$, where ' $t$ ' is the year in which the household was interviewed. Take for example a household in 1997 headed by a 65-year-old, a member of the 1930-1934 cohort; in 2007 this household is headed by a 75-yearold, but remains a member of the 1930-1934 cohort; this study delineates the separate effects of age and cohort on the decision to undertake a trip for personal purposes, and on tourism expenditure.

In Table 1, the definition of cohorts, householders' age in the first and last year of observation, and the size of the cohorts are reported. The size of all cohorts is very large and quite stable across cohorts, with the exception of the first (Cohort_1) and the last cohort (Cohort_14) which are smaller and so less representative. In the light of that, we exclude households whose head was born after 1979 and before 1920; viz. where the householder was 18 or 77 years old in 1997. This reduces the sample size to 253,858 households.

$<<$ Table 1 about here $>>$

\footnotetext{
3 For each household member, BF surveys the individual's age by using a categorical variable subdivided in 15 age-classes. We provide some robust checks to support the use of the mid-range age-class value as the householder's age. The distribution of individuals within each age-class is quite uniform, largely supporting the use of the median value. Results are available from the Authors on request.
} 
The descriptive statistics reported in Table 1 show a high presence of non-tourism consumption (only $8 \%$ of all Italian households exhibit a positive expenditure) and a positive association between the intensity of participation and cohorts. The percentage of consuming households increases for the youngest cohorts and the highest participation rates are found for the middle cohorts (10\%); for the oldest cohorts, the percentage of households with a positive tourism expenditure decreases to $3 \%$. According to the life cycle theory and previous empirical literature, the percentage of households making a trip shows an inverted U-shape profile, where the highest percentage is found in middle-aged households.

A similar picture emerges from the analysis of expenditure by age class (Table 2). The total expenditure on tourism participation shows a 'normal' age profile (i.e. a bell-shaped profile) and a positive association between participation in tourism and age for both the destination choices (travelling domestically and abroad). The analysis also reveals that the total expenditure of tourists for each age class is always higher than the average expenditure of Italian households as a whole. This finding suggests the presence of a budget constraint in the decision to travel for personal purposes.

\section{$<<$ Table 2 about here $>>$}

In Figure 1, to better represent the age-cohort-time effects, the average values of the total expenditure and the tourism expenditure, obtained as the mean expenditure of each cohort from 1997 to 2007 against the age of the head of the household, are plotted. In each chart, a connected line represents the expenditure behaviour of a cohort over the 11 years of the analyzed period, which has a five-year overlap with the next cohort. The distance between lines indicates the difference between expenditure levels for those households with the same age but different year of birth; i.e. it measures the cohort-time effect. It is also possible to track the behaviour of households with different ages within each cohort in order to evaluate the effect of population ageing. The differences along the same line measure the age-time effect.

$<<$ Figure 1 about here $>>$

Figure 1a shows the life cycle pattern of the total expenditure which has a 'normal' age profile. The total expenditure grows in the first phases of the life cycle reaching its maximum values in middle age, and declines thereafter. A similar profile is detected for the total expenditure of 
households with non zero tourism consumption (Figure 1b), even if the hump-shaped profile is less pronounced. A comparison of Figure $1 \mathrm{a}$ and $1 \mathrm{~b}$ reveals that the level of consumption is always higher for the families who travel. The oldest cohorts report a total expenditure equal to almost twice the expenditure of the whole sample. We also note the presence of significant positive cohort effects for young and middle-age cohorts of tourists.

Figures 1c and 1d show, in general, an increasing dynamic of tourism expenditure in the first phases of the life cycle. The domestic tourism expenditure increases for the younger age classes, decreases for the middle age classes and peaks for the oldest ones. Tourism expenditure abroad has a quite similar dynamic although it is less pronounced.

\subsection{Model specification and selection}

As one of the main aims of the study is to investigate the existence of life cycle patterns in tourism participation and consumption decisions, the age-cohort-time decomposition structure has been included in both stages of the hurdle models. In particular, we model the age profile as the sum of a polynomial in the third degree of age, and the cohort and time effects by means of dummy variables. ${ }^{4}$ Following the suggestions of Heckman (1979) and Cragg (1971), different sets of factors are assumed to influence the decisions at each level. According to the literature on demography and tourism demand and taking into account the availability of data, we hypothesize that the decision to travel is influenced by the size of the family, the region where the family resides, and whether the family own their house. The participation decision is also expected to be influenced by some characteristics of the head of the household, such as gender, level of education, and employment status. As for the consumption decision, total household expenditure (used as a proxy for income) has been introduced by a linear and quadratic term to better reflect the shape of the Engel curve in tourism consumption. In particular, in the second hurdle we use a double-log specification for the tourism demand model. Finally, in order to control for seasonality three seasonal dummy variables have been introduced in both equations (Table 3).

\footnotetext{
4 Following MaCurdy and Mroz (1990) and Deaton and Paxson (1994) we model time dummies in order to solve the identification problem. Formally, the first and second year dummy variables are dropped from the model and the remaining year dummy variables are included in the model in a normalized form $\tau_{t}=d_{t}-(t-1) d_{t}+(t-2) d_{t}$, where $d_{t}$ is a year dummy (t: $\left.3, \ldots, \mathrm{T}\right)$. This transformation implies that all the year dummy variables add up to zero and makes the year effects orthogonal to a time trend, that is $\sum_{t: 1}^{T} \tau_{t}=0$ and $\sum_{t: 1}^{T} t^{*} \tau_{t}=0$
} 
$<<$ Table 3 about here $>>$

To identify the model specification that best describes decision-making in tourism, we make use of tests for nested and non-nested models. Likelihood ratio (LR) and Vuong tests (Vuong, 1989) have been calculated to check whether a double-hurdle model is superior either to the standard or generalized Tobit models (Table 4). Adjusted LR tests strongly reject the Tobit specification, confirming the presence of separate individual choice structures for participation and consumption decisions for both the tourism destination choices. Moreover, the Vuong test for nonnested models is used to compare the double-hurdle with the first-hurdle dominance model. The results of this test lead us to reject the hypothesis of model equivalence and to prefer the independent double-hurdle model (Cragg Model) to the Heckman specification for both the tourism destination models (Table 4).

$<<$ Table 4 about here $>>$

\section{Empirical Findings}

\subsection{Demographic effects}

In Table 5, the ML estimates of Cragg models have been reported. For the most part, our results are in agreement with previous findings on tourism demand. The estimates do show gender differences in tourism participation but only for the decision to travel abroad. Men are less likely to go abroad. Consistent with Hong et al. (2005), family size is positively associated with the likelihood of spending on tourism. Families with a higher number of members are more inclined to make a domestic trip than one abroad. These results are in agreement with Eugenio-Martin \& Campos-Soria (2011) who found family size negatively affects the probability of making a trip abroad.

In contrast to other studies based on previous time periods (see e.g. Alegre \& Pou, 2004; Eymann \& Ronning, 1997; Nicholau \& Más, 2005), we found that family size does not play a deterrent role in travel decisions. This can be explained by the increase in voluntary childlessness which is a feature of contemporary Italian society, and which has resulted in a reduction of the average household size (on average over the period the family size reduced by $13.6 \%$ ). Household 
size was slightly higher than the average value of 2.7 members only for households headed by baby boomer seniors and older seniors. Even if these cohorts have a higher than average household size, this is not a deterrent to travel because there are no school-age children at home, a factor which may make travelling difficult during the school term.

$<<$ Table 5 about here $>>$

It is worth noting that the occupation status of the head of the household significantly affects tourism participation. The occupation status of the householder e.g. unemployed and housewife negatively affects the probability of participating in tourism activity at international and national level. We found the same to be true also for students which is different from what is found in the literature. This may be due to the fact that in the tourism participation equation we do not consider economic variables like income which are usually considered together with personal characteristics in micro-econometrics studies on tourism demand (see e.g. van Soest \& Kooreman 1987). Their exclusion is motivated by the discrete random preference theory, according to which sample selection is determined exclusively by noneconomic factors (Pudney, 1989). In the light of that, it may be hypothesized that the negative sign of the coefficient of student reflects mostly economic constraints on the decision to travel. In contrast, the occupation status of retired people acts positively on both the destination choices. Families whose head has a job at managerial level or is self-employed are more likely to travel to both destinations. Office workers are more likely to travel than manual workers.

As occupation status indirectly reflects the economic condition of a family, the results lead us to state that increased income strongly and positively affects the decision to travel. Similar considerations can be made regarding the level of education which mirrors cultural and economic constraints and affects ease of access to information. Individuals who have a degree or a secondary school certificate are more likely to travel, whereas households with a head who has a middle school certificate show a lower propensity to travel. The level of education is a highly relevant determinant of tourism participation at international and national level.

Consistent with Cai et al. (1995), significant differences were found for the variables related to the region of residence. The analysis shows that families living in regions where there are high levels of unemployment, low levels of income and a high stock of natural and cultural resources (i.e. Southern regions) are less inclined to make a trip than those households in regions where there are either better living conditions (i.e. low levels of unemployment and high levels of 
income) or maybe a less favourable climate (i.e. Northern regions). Furthermore, families living in regions where there are more opportunities to access the transport system e.g. airports, highways, and a more efficient rail network, etc. (i.e. Northern regions) are likely more inclined to travel than those households living in regions where the infrastructure is poor (i.e. Southern regions). On the other hand, the negative sign of the coefficient of South variable could reflect the fact that families in the South of Italy have less desire to travel either in Italy itself or abroad because they can enjoy the good climatic conditions, the abundant natural resources (e.g. the sea) and the artistic and cultural amenities found there. Thus, the residence place takes in both territorial differences in natural and cultural amenities, as well as socio-economic differences among families in terms of living conditions in a wider sense.

Interestingly, home ownership has a positive effect on the decision to travel. This result is consistent with the literature that hypothesizes that the level of resources positively affects the likelihood of spending on tourism and that home ownership is an indicator of well-being (see Hong et al. 2005; Bernini \& Cracolici, 2014).

\subsection{Age and cohort effects}

Using the Wald test, we first verify whether the age and cohort effects are statistically significant (Table 6). Tests confirm the presence of a life cycle pattern in both the participation and consumption decisions, even if the pattern is different in each case. The same can also be said about the decision to travel domestically or abroad (Figures 2 and 3).

\section{$<<$ Table 6 about here>>}

By means of a graphical analysis, we explore in more depth the pattern of cohort and age effects on tourism demand. Looking at the decision to make a trip in Italy, the estimated cohort parameters increase monotonically, demonstrating that older cohorts have a higher probability of having a trip than younger ones (Figure 2a). To be precise, older cohorts are more inclined to participate in the tourism market. Differences in the attitude, preferences and behaviour of cohorts towards travel reflect the personal experiences that people born in different years have had as well as a better life and improved economic conditions. With more money, time, and an active lifestyle, older cohorts are the fastest-growing market segment in the travel and tourism industry (Jang \& Ham, 2009). As for the age effect, the probability of travelling domestically decreases over a lifetime. Similar to 
previous literature (Alegre \& Pou, 2004; Alegre et al. 2010), we find that the likelihood of making a trip changes with age and the oldest people show a lower potential participation in tourism (Figure 2b). These results agree with Alegre \& Pou's (2004) findings that the ageing of a population has an ambiguous effect on tourism demand. Having a greater proportion of elderly people negatively affects tourism demand but this effect is compensated for by a positive cohort effect.

As far as the tourism consumption decision is concerned, the pattern is opposite for cohort and age effects when compared to the participation decision (Figures $2 \mathrm{c}-2 \mathrm{~d}$ ). The oldest cohorts spend less than the youngest ones. In line with Alegre et al. (2013), we find that domestic tourism expenditure increases over a lifetime, that is the oldest people spend more than the youngest ones. Thus, age and cohorts influence the participation and consumption equation in opposite ways.

$<<$ Figure 2 about here $>>$

Looking at the decision to participate in the international tourism market, Figure 3 highlights the fact that there are different cohort and age patterns compared to the domestic tourism choice. An almost U-shaped cohort pattern for the decision to travel abroad is detected, with a hump for middle cohorts (Figure 3a) and with the oldest cohorts having a higher participation level. The latter is in line with the study by Li et al. (2013), who found that older generations have travelled more outside the U.S. than their younger counterparts. This result is partially weakened by the non statistical significance of the estimated parameters of Cohort_ 8, _9 and _10, even if the Wald test gave evidence that an overall cohort effect existed in the participation model. Similar to domestic tourism, the probability of travelling abroad decreases as age increases and it reaches its minimum value for the oldest people (Eugenio-Martin \& Campos-Soria, 2011). As for consumption, there is a slight reduction in the propensity to spend across cohorts in comparison to the Italian market. This cohort pattern is associated with a positive and increasing age effect: over a lifetime householders increase their foreign tourism expenditure (Figure 3d). Similar findings are reported in the study by Jang et al. (2004), who also show that age has a positive impact on international travelling expenditure, irrespective of the households' income.

$<<$ Figure 3 about here $>>$

To summarize, Italian households exhibit a decreasing propensity to participate in tourism over a lifetime, but a higher propensity to spend. The lower participation propensity of the elderly is 
related to increased health and mobility problems (You \& O'Leary, 2000). However, once the decision to make a trip has been taken, older people spend more on tourism than younger people. The rationale is that in the early stage of the life cycle families tend to store durable goods, while over a lifetime, expenditure on durable goods reduces and is substituted by consumption of recreational and leisure goods, like tourism (Wagley and Huh, 2004). The fact that older people are less inclined to travel, but on average spend more money on tourism than younger people is true for both domestic and international tourism demand.

Over time cohorts have modified their tourism behaviour, more markedly in the domestic market, with the oldest cohorts being more likely to make a trip (You \& O'Leary, 2000), but spending less. In particular, the oldest cohorts show a higher propensity to travel due either to their domestic life or to budget constraints. The oldest cohorts have more leisure time available for travelling than the youngest cohorts because their children are older or have moved away from home, as the reduction in the family size suggests (over the analysed period, the size reduces by about $25 \%$ for the oldest cohorts, but increases by $20 \%$ for the youngest ones). However, the oldest cohorts have budget constraints that negatively affect expenditure on tourism. They suffered more than the younger cohorts from the crisis of the nineties, which largely penalized retired people (e.g. the Pension Reform Act of 1992).

The picture that emerges, considering age and cohort effects simultaneously, is interesting. The oldest people travel less and spend more on average than the youngest (age effect), but compared to tourists of the same age in the past (cohort effect), the oldest cohort participates more actively in the tourist market, but on average they spend less. These effects are also present in the international market, but they must be carefully interpreted as some estimates are not significant.

\subsection{Tourism demand elasticity}

In order to explore in greater depth the relationship between total expenditure (used as a proxy of income) and tourist expenditure, we have calculated the income elasticity5 (Blundell et al., 1993) with respect to the percentile of income, and the age and cohort of the householder. As underlined by the literature (see e.g. Crawford \& Godbey, 1987), income is a personal budget

\footnotetext{
5 Expenditure (or income) elasticities are computed according to Blundell et al. (1993), viz.elasticities reported in the paper are calculated at the mean value of the total expenditure of the reference group (age class, cohort, income percentiles, overall sample).
} 
restriction which determines spending capacity and is taken into account to maximize utility. The empirical literature shows that medium-high and high income groups are more likely to take vacations (Bardon 1991; Hay and McConnell 1979; Walsh et al 1992), supporting the idea that tourism behaves as a normal good with positive demand-income elasticity, increasing its consumption as income increases (Davis and Mangan 1992; Middleton 1994). Our results are in agreement with this line of research.

The mean value of income elasticity decreases across income percentiles (Figure 4). For those families in the first percentile the consumption of tourism is a luxury good, whereas for higher levels of income, tourism progressively becomes a necessary good. There is a difference in income elasticity between the decision to participate in the national market with that in the international tourism market. It is always higher for the spending decision to travel abroad, but the difference almost disappears for the highest levels of income; viz. the richest households are indifferent to the choice of destination. Domestic tourism is a necessary good for those families with a level of income higher than the first quartile. The same can be said about making a trip abroad for those families with a level of income greater than the median value. The choice of destination - a domestic or foreign trip - changes with income, but for higher levels of income the elasticity tends towards zero and differences in income elasticity related to the choice of the destination are more attenuated.

$<<$ Figure 4 about here>>

Figure 5 reports the mean income elasticity value for the cohort and the age of the householder. It highlights relevant ageing and cohort effects in the consumption of tourist goods and services. Income elasticity has a non-linear relationship with respect to age and cohort with a U-shaped life cycle profile. Moreover, the average value of income elasticity for age and cohort for the international market is higher than for the domestic one, 0.96 compared to 0.81 . More precisely, the income elasticity for cohort and age is - with the exception of the middle-age classes and cohorts - greater than 1, indicating that spending on tourism is a luxury good for the majority of the classes of age and cohort. For households travelling domestically, however, tourism is a necessary good, for every age and cohort the value of income elasticity being less than 1 (on average the demand elasticity is equal to 0.81 ).

$<<$ Figure 5 about here $>>$ 
To sum up, the youngest and oldest people show higher values of elasticity, suggesting that they have a greater propensity to respond to variations in their income. Their demand elasticity is more sensitive to income changes than that of middle-aged people. This finding is related to family constraints and reflects the life cycle model. In the first phase of life the householder and his/her partner likely pay more attention to the basic needs of their children such as education, health, sports activities, etc.; so they are less inclined to spend on unnecessary goods like tourism. Their income is also the lowest among the other age classes (on average over the analysed period, the income of the younger families is one third lower than that of the middle ages, and 15\% less than the income of the oldest ones), limiting the spending capacity of these households. While, in the mature phase of life, changes in the structure of the family (e.g. the job stability of children, a change of marital status of children or an increase in the number of wage earners) and consequently in the composition of family expenditure, have a positive impact on participation in tourism. During this stage of life, household income reaches its highest levels and the number of family members starts to reduce as children leave home; that is 'interpersonal barriers' decrease (Crawford \& Godbey 1987). Later on during retirement, people are again sensitive to tourism consumption, reflecting variation in preferences, liquidity constraints and intergenerational transmission of economic resources. With retirement, on average, household income reduces by $20 \%$ negatively affecting expenditure on non-basic goods. Moreover, as underlined by Wagley and Huh (2004), there is a shift in preferences toward leisure among retired people and their marginal propensity to consume leisure is significantly increased, implying a greater income elasticity for leisure goods in retirement.

Comparing income elasticity profiles by age and cohort (Figure 5), we find some further interesting evidence. For both domestic and foreign demand, income elasticity by age is higher than that by cohort until we reach the middle-age classes. For higher age classes on the other hand, the income elasticity is lower than that by cohort. In the light of that, we can say that the youngest people show a higher sensitivity to income and that this sensitivity has decreased over time, as suggested by the lower value of the cohort elasticity for the youngest cohorts. Conversely, the oldest cohorts have become more sensitive to variations in their income over the analysed period. This finding is related to the budget constraints faced by these households, who have an average income which is $20 \%$ and $25 \%$ lower than that of the youngest and middle cohorts, respectively. The economic crisis of the nineties had a negative impact on households and its effect was felt more by the retired with the oldest cohorts having a significant reduction in their income over the 
analyzed period (1997-2007). In light of this, marketing strategy on tourism demand should provide incentives to participate in tourism for households whose head is from the youngest and oldest age classes, promoting cheaper and more attractive tourist packages.

\section{Conclusions}

Based on the framework of the life cycle theory, the study aims to investigate how demographic dynamics, with particular attention to age and cohort, impact on the decision making process in tourism at national and international level. By means of Hurdle models, the paper focuses on two stages of the tourist decision process: whether or not to participate in the tourism market and how much to spend.

Looking at the tourism participation decision, this study highlights that the probability of a household making a trip for personal purposes is related to cultural, socio-economic and cohort factors. The level of education is the main determinant on the decision to participate in tourism, and such knowledge is useful for defining appropriate strategies of market segmentation demand. An individual with a high level of education is more likely to reach an adequate job position and a higher level of income which could be spent on non-basic needs like tourism. Furthermore, people with a higher level of education access information more easily. This knowledge likely increases the desire to discover new destinations and enjoy new experiences. Finally, regarding the choice of destination, it is worth noting that participation in the international tourism market is positively supported by variables related to the level of education.

This matter could represent a threat for Italian tourism if it is not effectively managed. The fact that people with a high level of education want to travel abroad may act negatively on the national flows of tourism and consequently on the economy of the Italian destinations. We live in a globalized and mobile world where easier access to transport and information stimulates people to travel towards non-traditional and remote destinations. Since this trend cannot be halted, a strategic and innovative policy for the development of tourism will involve destination management organizations (DMO) working hard to strengthen loyalty to the Italian brand. In line with a sustainable approach to tourism development, the policy should be to maintain market shares and not simply to attract potential new tourists, fostering, for example, co-production of brands (e.g. gastronomy and cultural tourism) (see e.g. Hankinton, 2004) or product innovation to improve and diversify the traditional product (see e.g. Hjalager, 2010). This would add value for 
customers who would be more inclined to try new experiences which would reinvigorate their loyalty to the Italian product.

Among the socio-economic variables, occupation status is a significant social and economic discriminating factor in tourism participation. Households whose head does not actively participate in the labour market are less likely to make a trip . On the other hand, families where the householder has a prestigious job are more likely to participate in tourism and are more likely to travel abroad than to travel domestically.

Regional differences are predicted to have an association with the likelihood of spending on tourism. Individuals living in the North of Italy are more likely to go away for a trip whereas households resident in the South are less likely to. The residence place mirrors not only economic and amenity differences, but also cultural differences between the two areas.

The study shows that the participation decision is affected significantly by ageing and cohort effects. Households are less likely to travel but spend more on tourism over a lifetime, independent of the destination choice.

Looking at the cohort effect, the oldest cohorts are more inclined to participate in tourism than the youngest one, but they are less inclined to spend on tourism. Cohort effects also mitigate age effects, viz. over a lifetime - as supported by the life cycle theory - people are less inclined to travel (age effect) (see Rapport \& Rapport 1975), but the propensity to participate in tourism has increased over time (cohort effect). This attitude may be due to the fact that in recent decades, people have more leisure time and better health in the last phase of the life cycle. The latter has fostered the spread of 'young at heart' behaviour among older people which positively supports their tourism participation. Added to this, the significant cohort effect indicates that the oldest cohorts want to escape from daily life and spend more time having a healthy holiday (see e.g. Szromek et al., 2012). Conversely, even if the oldest people spend the most on tourism, over time this behaviour has been diminishing; that is, the oldest cohorts are less predisposed to spend on tourism than before. There are two main reasons for this behaviour. First, households likely want to take care of the future cohorts by supporting them through intergenerational transfers of their savings. Second, older people are likely more attracted by other alternative recreational and cultural goods like theatre, art exhibitions, concerts, sport activities, dance, etc. These activities are similar to tourism in that they provide a means of escape from everyday life, but they are a type of recreation that does not involve leaving home and they are relatively cheap. Nevertheless, the intensity of tourism consumption is still higher for older people. This information is essential for tourism marketing strategists because older people could be a greater source of revenue. Suitable 
marketing ploys should be put in place to increase the expenditure of older tourists reinforcing their inclination to spend more than younger people do.

All of this, coupled with the ageing dynamic of the population at a worldwide level, present new challenges to the tourism industry. The negative relationship between age and tourism participation could become a threat if it is not well monitored by the DMOs through marketing strategies which lessen the negative age effect and exploit the positive cohort effect. New and reinvented tourist products able to reach and satisfy the needs of the niche market of the older cohorts - set to become a booming market - should be designed, packaged and delivered. The estimates of elasticity highlight a great diversity in the sensitivity of tourism to expenditure, for income level, destination or over the life cycle. It has also been confirmed that tourism is a luxury good for the poorest families, but as income increases it becomes a necessary good. The U-shaped profiles of income elasticity over the life cycle for the national and the international market are slightly different. Over the life cycle, income elasticity changes for at least two distinct reasons: ageing and cohort effects. The youngest people are seen to be highly sensitive to income but this sensitivity decreases as age increases. Conversely, the oldest cohorts have become less reactive to variations in their income over time. The main message from the results is that the youngest and the oldest are the most sensitive to income changes and constraints relating to income. Furthermore, the response to changes in income and the life cycle has varied over time. Several features may influence the dynamic of income elasticity in tourism like changes in individual preferences, the business cycle, the new emerging destinations, etc.

The analysis has shown that there is great diversity among households as to whether they participate in tourism. Therefore the analysis of tourism demand should clearly explore both stages of the tourism decision-making process simultaneously to better explore and differentiate the determinants of the two different stages. Finally, the empirical results have highlighted the relevance of enlarging the set of explanatory variables. This will enable the effects of demographic dynamics on tourism to be better understood and the most suitable policies and marketing actions to be identified.

\section{References}

Aguiar, M., \& Hurst, E. (2013). Deconstructing Lifecycle Expenditure. Journal of Political Economy, forthcoming. 
Alegre, J., \& Pou, L. (2004). Micro-economic determinants of the probability of tourism consumption. Tourism Economics, 10(2), 125-144.

Alegre J., Mateo S., \& Pou, L. (2009). Participation in tourism consumption and the intensity of participation: an analysis of their socio-demographic and economic determinants. Tourism Economics, 2009, 15 (3), 531-546.

Alegre J., Mateo S., \& Pou, L. (2010). An analysis of households' appraisal of their budget constraints for potential participation in tourism. Tourism Management, 31, 45-56.

Alegre J., Mateo S., \& Pou, L. (2013). Tourism participation and expenditure by Spanish households: The effects of the economic crisis and unemployment. Tourism Management, 39, 37-49.

Alston, J. M., Chalfant, J. A. \& Piggott, N. E. (2002). Estimating and testing the compensated double-log demand model. Applied Economics, 34, 1177-1186.

Aristei, D., Perali, F., \& Pieroni, L. (2008). Cohort, Age and Time Effects in Alcohol Consumption by Italian Households: A Double-hurdle Approach, Empirical Economics, 35, 29-61.

Attanasio, O., \& Weber, G. (1994). The UK Consumption Boom of the Late 1980s: Aggregate Implications of Microeconomic Evidence. The Economic Journal, 104(427), 1269-1302.

Attanasio, O., Banks, J., Meghir, C., \& Weber, W. (1999). Humps and bumps in lifetime consumption. Journal of Business \& Economic Statistics, 17, 22-35

Balaguer, J., \& Cantavella-Jordá, M. (2004). Structural change in exports and economic growth: cointegration and causality analysis for Spain (1961-2000). Applied Economics, 36(5), 473-477.

Bardón, E. (1991). Resumen del Estudio sobre el Grado de Satisfacción de la Demanda Turística Nacional and Extranjera en relación con el Producto Turístico Español. Estudios Turísticos, 110, 65-123.

Bernini, C., \& Cracolici, M. F. (2014). Is participation in the tourism market an opportunity for everyone? Some evidence from Italy. Tourism Economics, doi.org/10.5367/te.2014.0409.

Blundell, R. W., Pashardes, P., \& Meghir, C. (1993). What do we Learn About Consumer Demand Patterns from Micro Data. The American Economic Review, 83, 570-597.

Blundell, R. W., Browning, M., \& Meghir, C. (1994). Consumer demand and the life-cycle allocation of household expenditure. Review of Economic Studies, 61, 57-80.

Browning, M., Deaton, A., \& Irish, M. (1985). A Profitable Approach to Labor Supply and Commodity Demands over the Life-Cycle. Econometrica, 53, 503-543.

Cai, L. A. (1998). Analyzing household food expenditure patterns on trip and vacations: a Tobit model. Journal of Hospitality \& Tourism Research, 22, 338-358. 
Cai, L. A. (1999). Relationship of household characteristics and lodging expenditure on leisure trips. Journal of Hospitality \& Leisure Marketing, 6(2), 5-18.

Cai, L. A., Hong, G., \& Morrison, A. M. (1995). Houshold Expenditure Patterns for Tourism Products and Services. Journal of Travel $\mathcal{E}$ Tourism Marketing, 4(4), 15-40.

Chen, R., Wong, K. A., \& Lee, H. C. (2001). Age, Period, and Cohort Effects on Life Insurance Purchases in the U.S. Journal of Risk and Insurance, 68(2), 303-27.

Collins, D., \& Tisdell, C. (2002). Aged-Related Lifecycles: Purpose Variations. Annals of Tourism Research, 29, 801-818.

Cragg, J. (1971). Some statistical models for limited dependent variables with application to the demand for durable goods. Econometrica, 39, 829-844.

Crawford, D., \& Godbey, G. (1987). Reconceptualizing Barriers to Family Leisure. Leisure Sciences, 9, 119-128.

Crawford, D., Jackson, E., \& Godbey, G. (1991). A hierarchical model of leisure constraints. Leisure Sciences, 13, 309-320.

Dardis, R., Derrick, F., Lehfeld, A., \& Wolfe, K. E. (1981). A cross-section of studies of recreation expenditures in the US. Journal of Leisure Research, 13(3), 181-194.

Davis, B., \& Mangan, J. (1992). Family Expenditure on Hotels and Holiday. Annals of Tourism Research, 19, 691-669.

Deaton, A. (1985). Panel data from time series of cross sections. Journal of Econometrics, 30, 109-126.

Deaton, A. (1992). Understanding consumption, Claredon Press, Oxford.

Deaton, A., \& Paxson, C. (1994). Intertemporal Choice and Inequality. Journal of Political Economy,102, 437-467.

Deaton, A. (1997). The Analysis of Household Surveys: A Microeconomic Approach to Development Policy. Baltimore, Johns Hopkins University Press.

Deaton, A., \& Irish, M. (1984). A Statistical Model for Zero Expenditures in Household Budgets. Journal of Public Economics, 23, 59-80.

Eymann, A., \& Ronning, G. (1997). Microeconometric Models of Tourists' Destination Choice. Regional Science and Urban Economics, 27, 735-761.

Eugenio-Martin, J. L., \& Campos-Soria, J. A. (2011). Income and the substitution pattern between domestic and international tourism demand. Applied Economics, 43(20), 2519-2531.

Federal Ministry of Economics and Technology. (2009). The impact of demographic change on tourism and conclusions for tourism policy. Germany: Federal Ministry of Economics and Technology. 
Fish, M., \& Waggle, D. (1996). Current income versus total expenditure measures in regression models of vacation and pleasure travel. Journal of Travel Research, 35, 70-74.

Fleischer, A., \& Pizam, A. (2002). Tourism constraints among Israeli seniors. Annals of Tourism Research, 29(1), 106-123.

Fleischer, A., \& Rivlin, J. (2009). Quality, quantity and duration decisions in household demand for vacations. Tourism Economics, 15(3), 513-530.

Glover, P., \& Prideaux, B. (2009). Implications of population ageing for the development of tourism products and destinations. Journal of Vacation Marketing, 15, 25-37.

Hall, C. M. (2005). Tourism: Rethinking the Social Science of Mobility. Harlow, UK: Prentice Hall.

Hall, C. M. (2006). Demography. In: Buhalis D and Costa C (eds) Tourism Management Dynamics: Trends, Management and Tools. Oxford, UK:Elsevier.

Hankinton, G. (2004). Relational network brands. Journal of Vacation Marketing,10(2), 109-121.

Hay, M., \& McConnell, K. (1979). An Analysis of Participation in Nonconsumptive Wildlife Recreation. Land Economics, 55, 460-471.

Heckman, J. (1979). Sample selection bias as a specification error. Econometrica 47, 153-161.

Hong, G. S., Fan, J. X., Palmer, L. \& Bhargava, V. (2005). Leisure Travel Expenditure Patterns by Family Life Cycle Stages. Journal of Travel \& Tourism Marketing, 18(2), 15-30.

Hjalager, A.-M. (2010). A review of innovation research in tourism. Tourism Management, 31, 1-12.

Jang, S., Bai, B., Hong, G., \& O'Leary, T. (2004). Understanding travel expenditure patterns. a study of Japanese pleasure travellers to the United States by income level. Tourism Management, 25, 331-341.

Jang, S., \& Ham, S. (2009). A double-hurdle analysis of travel expenditure: Baby boomer seniors versus older seniors. Tourism Management, 30, 372-380.

Jappelli, T. (1999). The age-wealth profile and the life-cycle hypothesis: a cohort analysis with a time series of Italian households. Review of Income and Wealth, 4, 57-75.

Lawson, R. (1991). Patterns of tourist expenditure and types of vacation across the family life cycle. Journal of Travel Research, 29, 12-17.

Li, X., Li, X. R., \& Hudson, S. (2013). The application of generational theory to tourism consumer behavior: An American perspective. Tourism Management, 37, 147-164.

MaCurdy, T. \& Mroz, T. (1990). Measuring Macroeconomic Shifts in Wages From Cohort Specifications. Mimeo, Stanford University.

McGehee, N. G., Loker-Murphy L., \& Uysal, M. (1996). The Australian international pleasure travel market: motivation from a gendered perspective. Journal of Tourism Studies, 7(1), 45-57. 
Melenberg, B., \& van Soest, A. (1996). Parametric and semi-parametric modelling of vacation expenditures. Journal of Applied Econometrics, 11, 59-76.

Mergoupis, T., \& Steuer, M. (2003). Holiday taking and income. Applied Economics, 35, 269-284.

Middleton, V. (1995). Managing the Marketing Mix. In: Witt, S. F. y Moutinho, L., eds., Tourism Marketing and Management Handbook, Prentice Hall, Hertfordshire.

Nicolau, J. L., \& Más, F. (2005). Stochastic modeling: a three-stage tourist choice process. Annals of Tourism Research, 32(1), 49-69.

Nickerson, N. P. (2000). Travel and recreation outlook 2000: Focusing on demographics. Montana Business Quarterly, 38(1).

Oppermann, M. (1995). Travel Life Cycle. Annals of Tourism Research, 22, 535-552.

Pudney, S. (1989). Modelling Individual Choice: The Econometrics of Corners, Kinks and Holes. Basil Blackwell, New York.

Rapoport, R., \& Rapoport, R. N. (1975). Leisure and the Family Life Cycle. Routledge and Kegan Paul: London.

Reece, W. R. (2004). Are senior leisure travellers different?. Journal of Travel Research, 43(1), 11-18.

Sakai, M., Brown, J., \& Mak, J. (2000). Population Aging and Japanese International Travel in the 21st Century. Journal of Travel Research, 38, 212-220.

Sedgley, D., Pritchard, A., \& Morgan, P. (2011). Tourism and ageing. A transformative research agenda. Annals of Tourism Research, 38, 2,422-436.

Szromek, A. R., Januszewska, M., \& Romaniuk, P. (2012). Demographic phenomena and demand for health tourism services correlated in Poland. America Journal of Tourism Research, 1(1), 10 20.

Tobin, J. (1958). Estimation of relationships for limited dependent variables. Econometrica, 26, 24-36.

van Soest, A., \& Kooreman, P. (1987). A micro-econometric analysis of vacation behaviour. Journal of Applied Econometrics, 2, 215-226.

Vuong, Q. H. (1989). Likelihood ratio test for model selection and non-nested hypotheses. Econometrica, 57, 307-333.

World Tourism Organization \& European Travel Commission. (2010). Demographic change and tourism. Madrid: World Tourism Organization \& European Travel Commission.

Walsh, R. G., John, K. H., McKean, J. R., \& Hof, J. G. (1992). Effect of Price on Forecasts of Participation in Fish and Wildlife Recreation: An Aggregate Demand Model. Journal of Leisure Research, 24(2), 140-156. 
Weagley, R., \& Huh, E. (2004). The impact of retirement on household leisure expenditures. Journal of Consumer Affairs, 38(2), 262-281.

Wells, W. \& Gubar, G. (1966). The Life Cycle Concept in Marketing Research. Journal of Marketing Research, 3, 355-363.

Yeoman, I., Hsu, C. H. C., Smith K. A., \& Watson, S. (2011). Tourism and Demography. Oxford, UK: Goodfellow Publishers.

Yeoman, I., Schanzel, H., \& Smith, K. (2013). A sclerosis of demography : How ageing populations lead to the incremental decline of New Zealand tourism. Journal of Vacation Marketing, 19(2), 91-103.

You, H., \& O'Leary, J. T. (2000). Age and cohort effects: an examination of older Japanese travellers. Journal of Travel \& Tourism Marketing, 9(1/2), 21-42. 
Table 1. Cohort Definition

\begin{tabular}{llllll}
\hline Cohort & $\begin{array}{l}\text { Householder's } \\
\text { year of birth }\end{array}$ & $\begin{array}{l}\text { Householder's } \\
\text { age in 1997 }\end{array}$ & $\begin{array}{l}\text { Householder's } \\
\text { age in 2007 }\end{array}$ & $\begin{array}{l}\text { Total number } \\
\text { of } \\
\text { households }\end{array}$ & $\begin{array}{l}\% \text { of } \\
\text { households } \\
\text { with tourism } \\
\text { expenditure }\end{array}$ \\
\hline 1 & $>=1980$ & $<17$ & $<27$ & 3464 & $7 \%$ \\
2 & $1975-1979$ & $18-22$ & $28-32$ & 4340 & $8 \%$ \\
3 & $1970-1974$ & $23-27$ & $33-37$ & 11887 & $9 \%$ \\
4 & $1965-1969$ & $28-32$ & $38-42$ & 21306 & $9 \%$ \\
5 & $1960-1964$ & $33-37$ & $43-47$ & 25834 & $10 \%$ \\
6 & $1955-1959$ & $38-42$ & $48-52$ & 26068 & $10 \%$ \\
7 & $1950-1954$ & $43-47$ & $53-57$ & 26555 & $10 \%$ \\
8 & $1945-1949$ & $48-52$ & $58-62$ & 26854 & $10 \%$ \\
9 & $1940-1944$ & $53-57$ & $63-67$ & 24592 & $8 \%$ \\
10 & $1935-1939$ & $58-62$ & $68-72$ & 24824 & $7 \%$ \\
11 & $1930-1934$ & $63-67$ & $73-77$ & 21165 & $6 \%$ \\
12 & $1925-1929$ & $68-72$ & $78-82$ & 21522 & $4 \%$ \\
13 & $1920-1924$ & $73-77$ & $83-87$ & 18911 & $3 \%$ \\
14 & $<=1919$ & $>78$ & $>88$ & 7706 & $3 \%$ \\
\hline Total & & & & 265028 & $8 \%$ \\
\hline
\end{tabular}


Table 2. Average Monthly Total and Tourism Expenditure by Age

\begin{tabular}{lllll}
\hline Age & $\begin{array}{l}\text { Total } \\
\text { expenditure } \\
\text { for the } \\
\text { whole } \\
\text { population }\end{array}$ & $\begin{array}{l}\text { Total } \\
\text { expenditure for } \\
\text { households } \\
\text { with tourism } \\
\text { expenditure }\end{array}$ & $\begin{array}{l}\text { Tourism } \\
\text { expenditure } \\
\text { in Italy }\end{array}$ & $\begin{array}{l}\text { Tourism } \\
\text { expenditure } \\
\text { abroad }\end{array}$ \\
\hline $18-24$ & 1517 & 2365 & 299 & 721 \\
$25-29$ & 1746 & 2718 & 356 & 843 \\
$30-34$ & 1910 & 2891 & 466 & 866 \\
$35-39$ & 2021 & 3042 & 521 & 843 \\
$40-44$ & 2163 & 3267 & 525 & 825 \\
$45-49$ & 2274 & 3400 & 498 & 785 \\
$50-54$ & 2310 & 3444 & 486 & 682 \\
$55-59$ & 2199 & 3461 & 466 & 708 \\
$60-64$ & 1929 & 3216 & 470 & 837 \\
$65-69$ & 1665 & 2952 & 515 & 838 \\
$70-74$ & 1424 & 2623 & 461 & 770 \\
$>75$ & 1184 & 2527 & 490 & 791 \\
\hline Total & 1866 & 3154 & 488 & 786 \\
\hline Note: & data is expanded to the whole population by using the \\
expansion factor provided by ISTAT; data is deflated by using the \\
national consumer price index (base:1995).
\end{tabular}


Table 3. Descriptive Statistics

\begin{tabular}{|c|c|c|c|c|c|}
\hline \multirow{2}{*}{ Variable } & \multirow{2}{*}{ Description } & \multicolumn{2}{|c|}{ Domestic } & \multicolumn{2}{|c|}{ Abroad } \\
\hline & & Mean & $\mathrm{sd}$ & Mean & $\mathrm{sd}$ \\
\hline Quarter 1 & $\begin{array}{l}1 \text { if household is observed in the } 1^{\text {st }} \text { quarter of the year } \\
0 \text { otherwise }\end{array}$ & 0.140 & - & 0.173 & - \\
\hline Quarter 2 & $\begin{array}{l}1 \text { if household is observed in the } 2^{\text {nd }} \text { quarter of the year } \\
0 \text { otherwise }\end{array}$ & 0.224 & - & 0.234 & - \\
\hline Quarter 4 & $\begin{array}{l}1 \text { if household is observed in the } 4^{\text {th }} \text { quarter of the year } \\
0 \text { otherwise }\end{array}$ & 0.111 & - & 0.161 & - \\
\hline Size_fam & Number of family members & 3.001 & 1.208 & 2.901 & 1.234 \\
\hline Unemployed & $\begin{array}{l}1 \text { if householder is looking for a job } \\
0 \text { otherwise }\end{array}$ & 0.012 & - & 0.010 & - \\
\hline Housewife & $\begin{array}{l}1 \text { if householder is a housewife } \\
0 \text { otherwise }\end{array}$ & 0.004 & - & 0.002 & - \\
\hline Student & $\begin{array}{l}1 \text { if householder is s student } \\
0 \text { otherwise }\end{array}$ & 0.002 & - & 0.003 & - \\
\hline Retired & $\begin{array}{l}1 \text { if householder is retired } \\
0 \text { otherwise }\end{array}$ & 0.275 & - & 0.260 & - \\
\hline Manager & $\begin{array}{l}1 \text { if householder is a Manager } \\
0 \text { otherwise }\end{array}$ & 0.036 & - & 0.053 & - \\
\hline Managerial Staff & $\begin{array}{l}1 \text { if householder is Managerial Staff } \\
0 \text { otherwise }\end{array}$ & 0.061 & - & 0.069 & - \\
\hline Office Worker & $\begin{array}{l}1 \text { if householder is an Office Worker } \\
0 \text { otherwise }\end{array}$ & 0.216 & - & 0.211 & - \\
\hline Manual Worker & $\begin{array}{l}1 \text { if householder is a Manual Worker } \\
0 \text { otherwise }\end{array}$ & 0.141 & - & 0.116 & - \\
\hline Self Employed & $\begin{array}{l}1 \text { if householder is Self Employed } \\
0 \text { otherwise }\end{array}$ & 0.169 & - & 0.199 & - \\
\hline Male & $\begin{array}{l}1 \text { if householder is male } \\
0 \text { otherwise }\end{array}$ & 0.812 & - & 0.791 & - \\
\hline High Education & $\begin{array}{l}1 \text { if householder has a Degree } \\
0 \text { otherwise }\end{array}$ & 0.135 & - & 0.171 & - \\
\hline $\begin{array}{l}\text { Secondary school } \\
\text { Education }\end{array}$ & $\begin{array}{l}1 \text { if householder has a secondary school education certification } \\
0 \text { otherwise }\end{array}$ & 0.383 & - & 0.395 & - \\
\hline $\begin{array}{l}\text { Middle school } \\
\text { Education }\end{array}$ & $\begin{array}{l}1 \text { if householder has a middle school education certification } \\
0 \text { otherwise }\end{array}$ & 0.282 & - & 0.243 & - \\
\hline North & $\begin{array}{l}1 \text { if the household resides in the North } \\
0 \text { otherwise }\end{array}$ & 0.460 & - & 0.538 & - \\
\hline South & $\begin{array}{l}1 \text { if the household resides in the South } \\
0 \text { otherwise }\end{array}$ & 0.188 & - & 0.113 & - \\
\hline Owned Home & $\begin{array}{l}1 \text { if household is the owner of home } \\
0 \text { otherwise }\end{array}$ & 0.776 & - & 0.787 & - \\
\hline LnExpTur & Logarithm of household tourism & 5.694 & 1.076 & 6.195 & 1.020 \\
\hline LnExpTot & Logarithm of household real total expenditure & 7.902 & 0.504 & 8.098 & 0.504 \\
\hline $\begin{array}{l}\text { LnExpTot } \\
\text { squared }\end{array}$ & Logarithm of household real total expenditure squared & 62.706 & 8.030 & 65.938 & 8.220 \\
\hline Ln_age & Logarithm of age of householder & 3.902 & 0.262 & 3.907 & 0.256 \\
\hline Ln_age squared & Logarithm of age squared of householder & 15.298 & 2.033 & 15.336 & 1.975 \\
\hline Ln_age cube & Logarithm of age cube of householder & 60.236 & 11.901 & 60.435 & 11.486 \\
\hline
\end{tabular}


Table 4. Specification Tests

\begin{tabular}{|c|c|c|c|}
\hline \multirow{2}{*}{ Model } & \multirow{2}{*}{ Test type } & Domestic & Abroad \\
\hline & & Test value & Test value \\
\hline \multirow[t]{2}{*}{$\begin{array}{l}\text { Independent double-hurdle model vs. } \\
\text { Tobit }\end{array}$} & Adjusted LR & $28874.720(27)$ & $10384.988(27)$ \\
\hline & & {$[0.000]$} & {$[0.000]$} \\
\hline $\begin{array}{l}\text { Independent double-hurdle model vs. } \\
\text { First-hurdle dominance Heckman model }\end{array}$ & Vuong & $35.504^{*}$ & $28.774^{*}$ \\
\hline
\end{tabular}


Table 5. ML Estimates of Double-hurdle Models

\begin{tabular}{|c|c|c|c|c|c|c|}
\hline & \multicolumn{3}{|c|}{ Domestic } & \multicolumn{3}{|c|}{ Abroad } \\
\hline & Coef. & Std. Err & $P>|z|$ & Coef. & Std. Err & $\mathrm{P}>|\mathrm{z}|$ \\
\hline & \multicolumn{6}{|c|}{ Tourism Participation } \\
\hline Cohort_3 & 0.036 & 0.043 & 0.405 & -0.011 & 0.054 & 0.833 \\
\hline Cohort_4 & 0.117 & 0.047 & 0.012 & -0.121 & 0.060 & 0.044 \\
\hline Cohort_5 & 0.120 & 0.051 & 0.020 & -0.200 & 0.067 & 0.003 \\
\hline Cohort_6 & 0.153 & 0.056 & 0.006 & -0.162 & 0.073 & 0.027 \\
\hline Cohort_7 & 0.152 & 0.060 & 0.011 & -0.135 & 0.079 & 0.088 \\
\hline Cohort_8 & 0.197 & 0.064 & 0.002 & -0.118 & 0.085 & 0.165 \\
\hline Cohort_9 & 0.268 & 0.068 & 0.000 & -0.111 & 0.091 & 0.220 \\
\hline Cohort_10 & 0.324 & 0.072 & 0.000 & -0.146 & 0.097 & 0.132 \\
\hline Cohort_11 & 0.412 & 0.077 & 0.000 & -0.170 & 0.103 & 0.099 \\
\hline Cohort_12 & 0.465 & 0.085 & 0.000 & -0.216 & 0.115 & 0.060 \\
\hline Cohort_13 & 0.582 & 0.093 & 0.000 & -0.131 & 0.127 & 0.300 \\
\hline 1999 & 0.012 & 0.014 & 0.389 & 0.018 & 0.019 & 0.332 \\
\hline 2000 & -0.002 & 0.013 & 0.871 & 0.042 & 0.018 & 0.019 \\
\hline 2001 & -0.009 & 0.014 & 0.489 & -0.011 & 0.019 & 0.573 \\
\hline 2002 & -0.013 & 0.013 & 0.342 & -0.043 & 0.018 & 0.018 \\
\hline 2003 & 0.002 & 0.013 & 0.846 & -0.036 & 0.018 & 0.039 \\
\hline 2004 & -0.021 & 0.014 & 0.118 & -0.002 & 0.018 & 0.926 \\
\hline 2005 & -0.012 & 0.013 & 0.365 & -0.003 & 0.018 & 0.878 \\
\hline 2006 & 0.004 & 0.013 & 0.734 & 0.004 & 0.017 & 0.818 \\
\hline 2007 & 0.029 & 0.013 & 0.022 & 0.027 & 0.017 & 0.101 \\
\hline Ln_age & -60.666 & 10.972 & 0.000 & -94.480 & 14.373 & 0.000 \\
\hline Ln_age squared & 16.985 & 2.908 & 0.000 & 25.650 & 3.835 & 0.000 \\
\hline Ln_age cube & -1.585 & 0.256 & 0.000 & -2.308 & 0.340 & 0.000 \\
\hline Quarter1 & -0.724 & 0.012 & 0.000 & -0.422 & 0.016 & 0.000 \\
\hline Quarter2 & -0.489 & 0.011 & 0.000 & -0.287 & 0.015 & 0.000 \\
\hline Quarter4 & -0.821 & 0.013 & 0.000 & -0.446 & 0.017 & 0.000 \\
\hline Size_fam & 0.075 & 0.004 & 0.000 & 0.039 & 0.006 & 0.000 \\
\hline Unemployed & -0.232 & 0.037 & 0.000 & -0.130 & 0.054 & 0.017 \\
\hline Housewife & -0.031 & 0.114 & 0.783 & -0.165 & 0.159 & 0.300 \\
\hline Student & -0.274 & 0.080 & 0.001 & -0.017 & 0.097 & 0.861 \\
\hline Retired & 0.094 & 0.019 & 0.000 & 0.076 & 0.026 & 0.004 \\
\hline Manager & 0.144 & 0.030 & 0.000 & 0.317 & 0.037 & 0.000 \\
\hline Managerial Staff & 0.197 & 0.026 & 0.000 & 0.239 & 0.034 & 0.000 \\
\hline Office Worker & 0.085 & 0.018 & 0.000 & 0.130 & 0.026 & 0.000 \\
\hline Manual Worker & -0.063 & 0.019 & 0.001 & -0.013 & 0.028 & 0.629 \\
\hline Self Employed & 0.039 & 0.019 & 0.039 & 0.184 & 0.026 & 0.000 \\
\hline Male & 0.005 & 0.012 & 0.687 & -0.041 & 0.016 & 0.012 \\
\hline Higher education & 0.387 & 0.018 & 0.000 & 0.395 & 0.023 & 0.000 \\
\hline Secondary School Education & 0.274 & 0.014 & 0.000 & 0.242 & 0.018 & 0.000 \\
\hline Middle School Education & 0.131 & 0.013 & 0.000 & 0.065 & 0.018 & 0.000 \\
\hline North & 0.137 & 0.010 & 0.000 & 0.180 & 0.013 & 0.000 \\
\hline
\end{tabular}




\begin{tabular}{|c|c|c|c|c|c|c|}
\hline South & -0.311 & 0.012 & 0.000 & -0.449 & 0.018 & 0.000 \\
\hline Owned home & 0.093 & 0.010 & 0.000 & 0.089 & 0.015 & 0.000 \\
\hline \multirow[t]{2}{*}{ Constant } & 70.562 & 13.746 & 0.000 & 113.372 & 17.888 & 0.000 \\
\hline & \multicolumn{6}{|c|}{ Tourism Consumption } \\
\hline $\operatorname{lnExpTot}$ & 4.335 & 0.303 & 0.000 & 5.060 & 0.504 & 0.000 \\
\hline $\operatorname{lnExpTot2}$ & -0.223 & 0.019 & 0.000 & -0.253 & 0.031 & 0.000 \\
\hline Cohort_3 & -0.172 & 0.078 & 0.027 & 0.101 & 0.103 & 0.326 \\
\hline Cohort_4 & -0.163 & 0.084 & 0.053 & 0.122 & 0.116 & 0.295 \\
\hline Cohort_5 & -0.182 & 0.093 & 0.049 & 0.069 & 0.132 & 0.599 \\
\hline Cohort_6 & -0.271 & 0.100 & 0.007 & -0.100 & 0.145 & 0.488 \\
\hline Cohort_7 & -0.400 & 0.107 & 0.000 & -0.070 & 0.155 & 0.654 \\
\hline Cohort_8 & -0.413 & 0.113 & 0.000 & -0.173 & 0.166 & 0.298 \\
\hline Cohort_9 & -0.481 & 0.120 & 0.000 & -0.057 & 0.177 & 0.747 \\
\hline Cohort_10 & -0.479 & 0.127 & 0.000 & -0.029 & 0.188 & 0.879 \\
\hline Cohort_11 & -0.510 & 0.136 & 0.000 & -0.064 & 0.203 & 0.751 \\
\hline Cohort_12 & -0.713 & 0.153 & 0.000 & -0.393 & 0.228 & 0.085 \\
\hline Cohort_13 & -0.886 & 0.171 & 0.000 & -0.396 & 0.258 & 0.125 \\
\hline 1999 & 107.422 & 20.487 & 0.000 & 81.104 & 31.970 & 0.011 \\
\hline 2000 & -29.183 & 5.438 & 0.000 & -22.525 & 8.522 & 0.008 \\
\hline 2001 & 2.643 & 0.480 & 0.000 & 2.077 & 0.755 & 0.006 \\
\hline 2002 & -0.090 & 0.024 & 0.000 & -0.038 & 0.037 & 0.309 \\
\hline 2003 & 0.097 & 0.023 & 0.000 & 0.133 & 0.036 & 0.000 \\
\hline 2004 & 0.087 & 0.024 & 0.000 & 0.120 & 0.038 & 0.002 \\
\hline 2005 & 0.087 & 0.024 & 0.000 & 0.112 & 0.037 & 0.003 \\
\hline 2006 & 0.022 & 0.023 & 0.345 & -0.028 & 0.036 & 0.440 \\
\hline 2007 & 0.011 & 0.024 & 0.644 & -0.071 & 0.036 & 0.049 \\
\hline Ln_age & -0.006 & 0.024 & 0.797 & -0.037 & 0.035 & 0.298 \\
\hline Ln_age squared & -0.012 & 0.023 & 0.605 & 0.049 & 0.035 & 0.164 \\
\hline Ln_age cube & -0.087 & 0.022 & 0.000 & -0.078 & 0.033 & 0.018 \\
\hline Quarter1 & -0.752 & 0.023 & 0.000 & -0.384 & 0.033 & 0.000 \\
\hline Quarter2 & -0.743 & 0.019 & 0.000 & -0.326 & 0.030 & 0.000 \\
\hline Quarter4 & -0.704 & 0.025 & 0.000 & -0.270 & 0.034 & 0.000 \\
\hline Constant & -145.822 & 25.651 & 0.000 & -114.924 & 39.890 & 0.004 \\
\hline Sigma & 0.925 & 0.005 & 0.000 & 0.882 & 0.008 & 0.000 \\
\hline Log-Likelihood & -69212.713 & & & -32159.957 & & \\
\hline
\end{tabular}


Table 6. Wald Tests of Joint Significance of Age and Cohort Effects

\begin{tabular}{lllll}
\hline & \multicolumn{2}{c}{ Domestic } & \multicolumn{2}{c}{ Abroad } \\
Equation & Cohort Effect & Age Effect & Cohort Effect & Age Effect \\
\hline \multirow{3}{*}{ Participation } & chi2(11) $=59.31$ & chi2(3) $=147.87$ & chi2(11) $=40.55$ & chi2(3) $=51.09$ \\
& p-value $=0.000$ & p-value $=0.000$ & p-value $=0.000$ & p-value $=0.000$ \\
& & & & \\
Consumption & chi2(11) $=43.64$ & chi2(3) $=45.31$ & chi2(11) $=52.51$ & chi2(3) $=17.17$ \\
& p-value $=0.000$ & p-value $=0.000$ & p-value $=0.000$ & p-value $=0.007$ \\
\hline
\end{tabular}


Figure 1. Average Expenditure by Age and Cohort

a) Average monthly expenditure

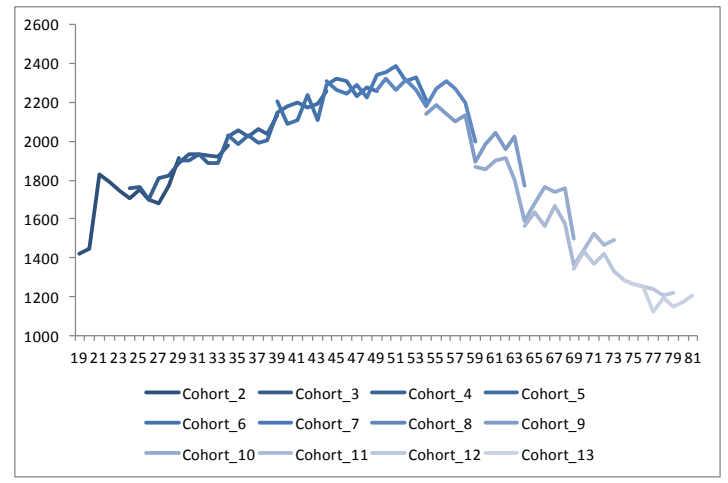

c) Average tourism expenditure in Italy

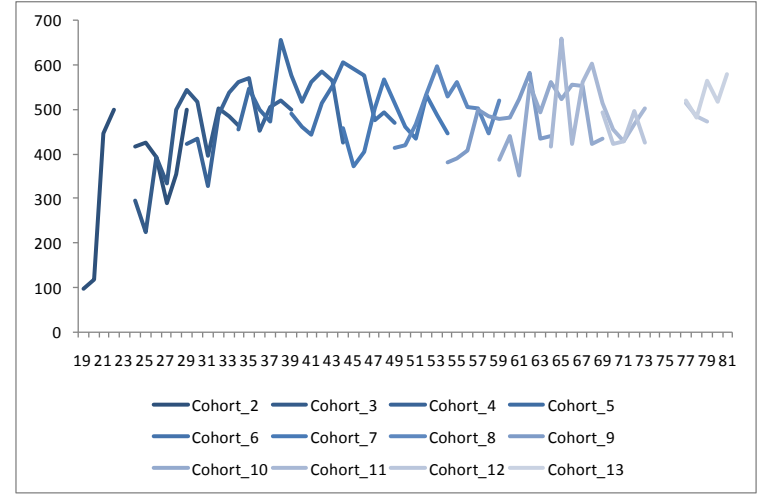

b) Average monthly expenditure for households with tourism expenditure

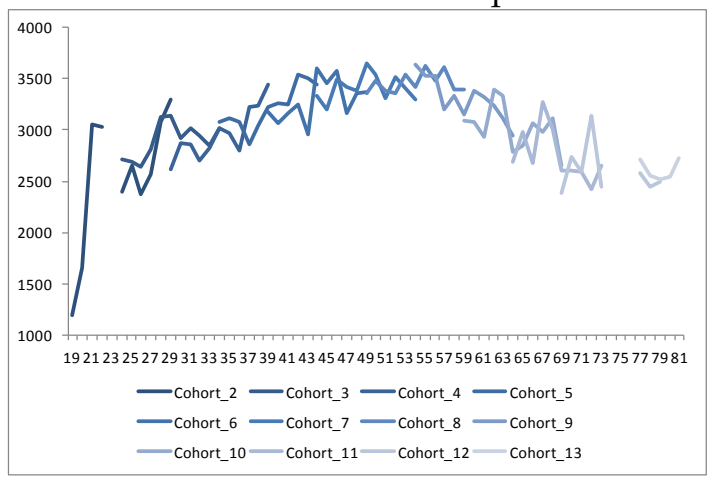

d) Average tourism expenditure abroad

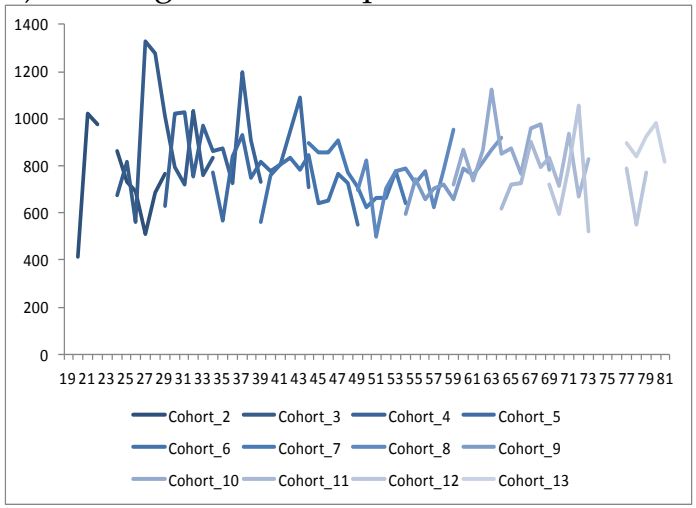


Figure 2. Cohort and Age Decomposition of Tourism Participation and Expenditure Decisions for a Domestic Holiday

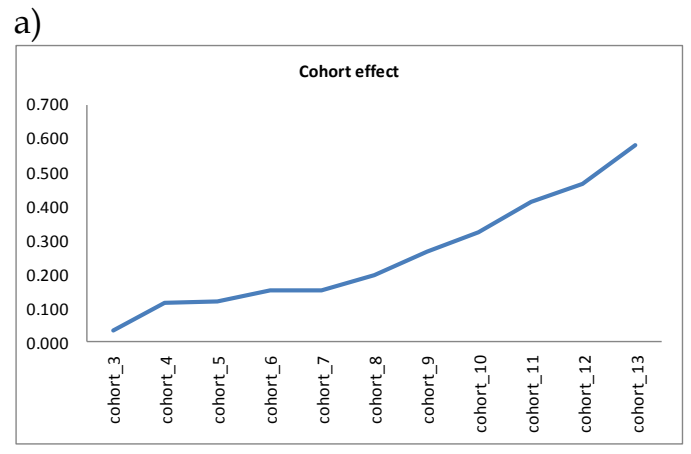

\section{Participation}



Expenditure

c)

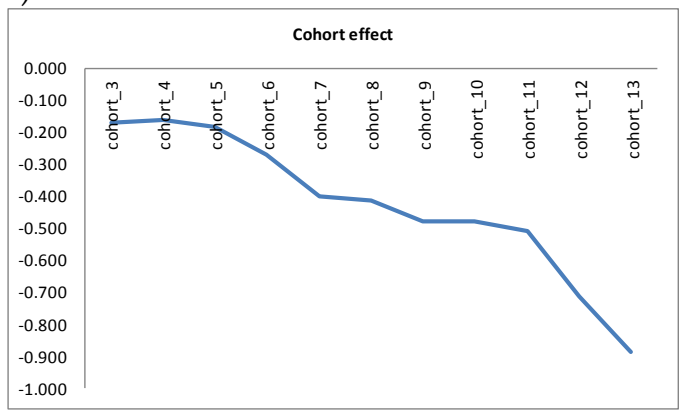

d)

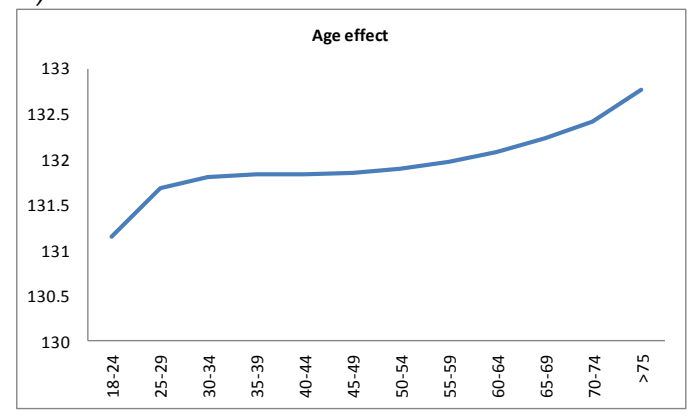


Figure 3. Cohort and Age Decomposition of Tourism Participation and Expenditure Decisions for a Holiday Abroad

a)

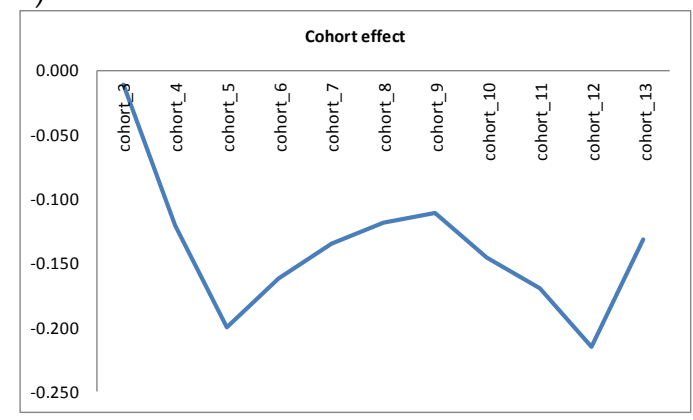

c)



Participation

b)

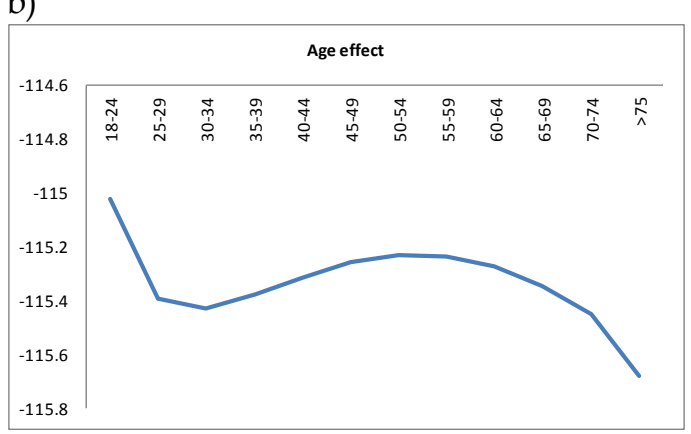

Expenditure

d)

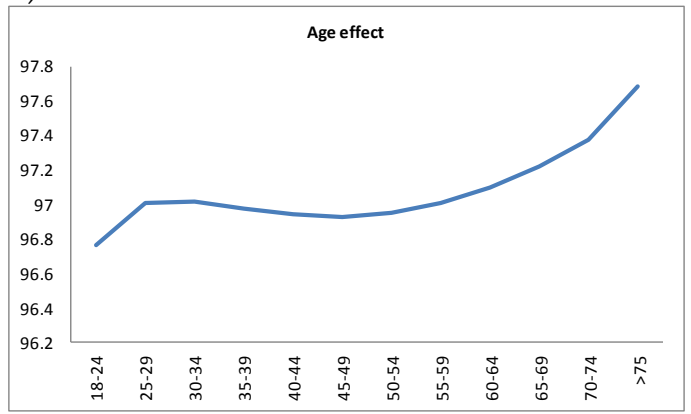


Figure 4. Elasticity by Total Expenditure Percentiles

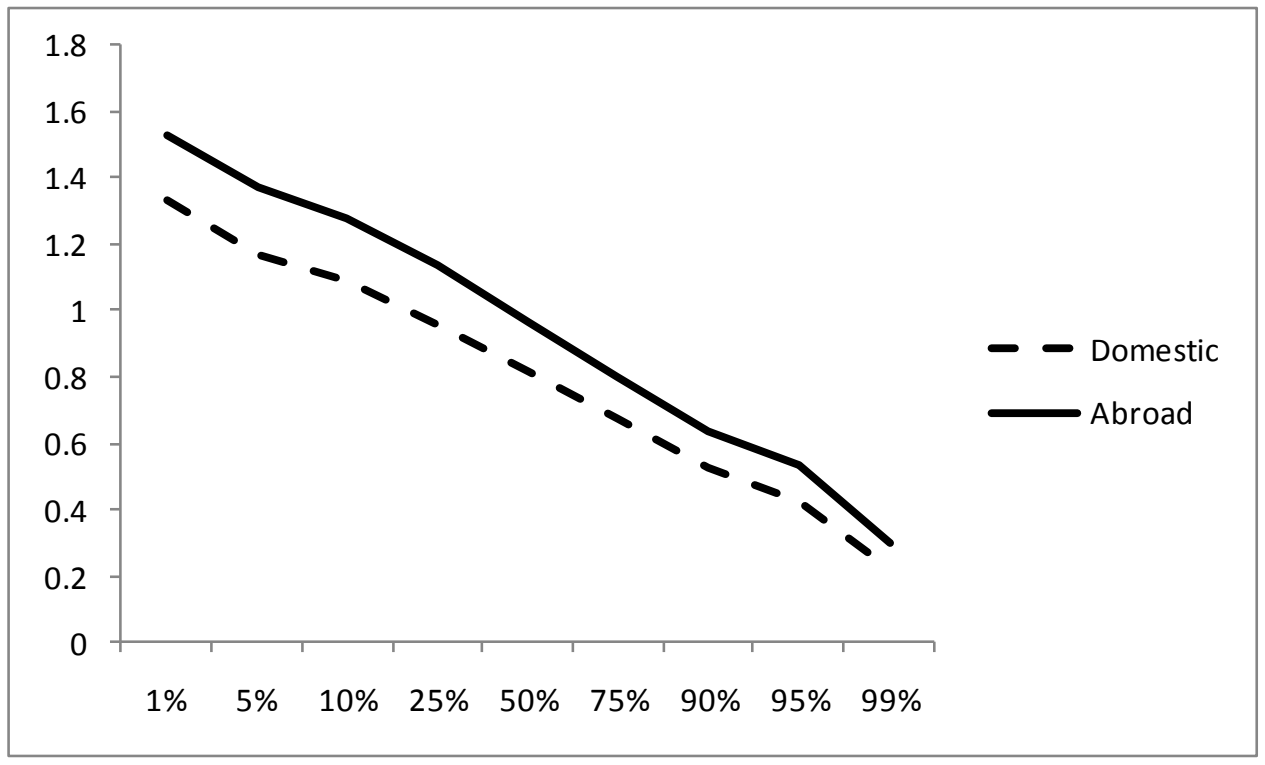

Figure 5. Comparing Elasticity by Age and Cohort

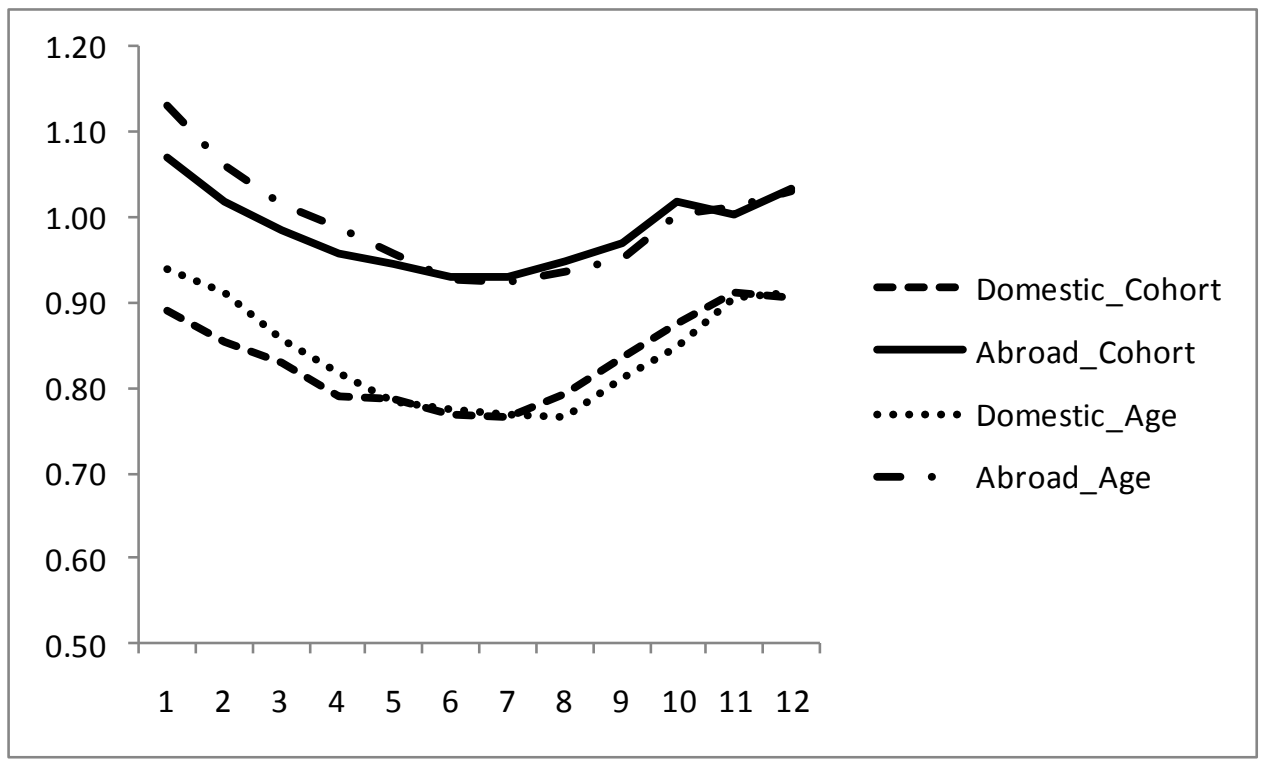

